\title{
Habeas Corpus Proceedings in the High Court of Parliament in the Reign of James I, 1603-1625
}

Donald E. Wilkes Jr.

University of Georgia School of Law, wilkes@uga.edu

P bepress

\section{Repository Citation}

Donald E. Wilkes Jr., Habeas Corpus Proceedings in the High Court of Parliament in the Reign of James I, 1603-1625, 54 Am. J. Legal Hist. 200 (2014),

Available at: https://digitalcommons.law.uga.edu/fac_artchop/971

This Article is brought to you for free and open access by the Faculty Scholarship at Digital Commons @ University of Georgia School of Law. It has been accepted for inclusion in Scholarly Works by an authorized administrator of Digital Commons @ University of Georgia School of Law. Please share how you have benefited from this access For more information, please contact tstriepe@uga.edu. 


\title{
Habeas Corpus Proceedings in the High Court of Parliament in the Reign of James I, 1603-1625
}

\author{
by DONALD E. WILKES, JR.*
}

In 1957, in the Temple Law Quarterly, Erwin Surrency wrote a book review of Catherine Drinker Bowen's biography of Sir Edward Coke, who in the fourth part of his Institutes had praised "the High and most Honourable Court of Parliament." Erwin had a great interest in early English history and was fascinated by its legal institutions. And no institution deserves more study than the High Court of Parliament, which, among its other attributes, served as a habeas court.

\footnotetext{
* Professor of Law, University of Georgia School of Law.
}

In this Article, the translations from Latin to English that are enclosed in brackets were made by the present author. Words abbreviated in the original Latin texts are expanded, including in the English translations. In preparing the translations the author was most ably assisted and advised by Will Owens, a 2011 graduate of the University of Georgia School of Law, to whom heartfelt gratitude is expressed.

\section{ABBREVIATIONS}

2 foster 2 Proceedings in Parlament, 1610, house of Commons (Elizabeth Read Foster ed., 1966)

1 Hatsell 1 John Hatsell, Precedents of the Proceedings in the House of ComMONS WITH OBSERVATIONS (photo. reprint 1971) (4th ed. 1818)

H.C.JOUR. JOURNAL OF THE HOUSE OF COMMONS

H.L.JOUR. JOURNAL OF THE HOUSE OF LORDS

$\mathrm{HL} / \mathrm{PO} / \mathrm{JO} / 10$ House of Lords: Parliament Office: Journal Office: Main Papers (Documents in the Parliamentary Archives of the United Kingdom relating to parliamentary habeas corpus proceedings are referenced by this designation followed by numerals successively indicating file, subfile, and item. Most of the habeas corpus-related documents in the Parliamentary Archives are originals, but some are copies or duplicate originals.)

HMC 3d Roval Historical Manuscripts COMmission, Third Report and APpenox (London, Her Majesty's Stationary Office 1872) 


\section{ABSTRACT}

English parliamentary habeas corpus proceedings have been neglected by scholars. This Article ends that neglect. This Article focuses on the parliamentary habeas corpus proceedings that occurred in the reign of King James I. The Article corrects several misunderstandings relating to the history of the writ of habeas corpus in England and to the history of the English Parliament (which in the seventeenth century commonly was referred to as the High Court of Parliament).

Part I of the Article provides answers to questions concerning the historical background and context of the parliamentary habeas corpus proceedings in the High Court of Parliament during James I's reign. What was the origin and significance of the term High Court of Parliament? What was the parliamentary privilege of freedom from arrest, the violation of which could lead to the granting of habeas corpus relief by the House of Lords or the House of Commons? What was the civil arrest system in effect in seventeenth century Englanda system which made it likely that from time to time the parliamentary privilege from arrest would be violated and the parliamentary habeas remedy thereupon invoked? What other remedies, apart from habeas corpus, were available to deal with infringements of the parliamentary arrest privilege? And what were the contours of the parliamentary habeas corpus remedy itself, which appears not to have been successfully invoked prior to the reign of James I?

Parts II and III conclusively demonstrate that in the reign of James I the High Court of Parliament at times functioned as the High Habeas Court of Parliament. Part II provides an indepth account of the habeas corpus proceedings in the House of Lords in the reign of James I, while Part III does the same

HMC 4th

$11 \mathrm{MHL}$
Royal historical Manuscripts Commission, Fourth Report, Part I, REPORT AND APPENDIX (London, Her Majesty's Stationary Office 1874)

11 The Manuscripts of the House of Lords, New Series, Addenda 1514-1714 (Maurice F. Bond ed., 1962) 
for the habeas corpus proceedings in the House of Commons during the reign.

The Article concludes with a detailed discussion of the three major changes this work mandates in our understanding of English legal history.

\section{TABLE OF CONTENTS}

INTRODUCTION

I. Habeas Corpus, Privilege, and the High Court of Parliament in THE REIGN OF JAMES I

A. THE HIGH COURT OF PARLIAMENT

B. THE PARLIAMENTARY PRIVILEGE OF FREEDOM FROM ARREST

C. THE CIVIL ARREST SYSTEM

D. NON-HABEAS PARLIAMENTARY REMEDIES FOR VIOLATIONS OF FREEDOM FROM ARREST

1. Release by Writ of Privilege

2. Release without Writ

3. Contempt Remedy

(a) House of Lords

(b) House of Commons

E. PARLIAMENTARY HABEAS REMEDY FOR VIOLATIONS OF FREEDOM FROM ARREST

II. Habeas Proceedings in the House of Lords, 1603-1625

A. OVERVIEW

B. PRACTICE AND PROCEDURE

1. Commencement of Proceeding

(a) Habeas Petitions

(b) Proceedings Without Petition

2. Issuance of Writ

3. Return to Writ

4. Post-Return Procedure

III. Habeas Proceedings in the House of Commons, 1603-1625

A. OVERVIEW

B. PRACTICE AND PROCEDURE

1. Commencement of Proceeding

2. Issuance of Writ

3. Return to Writ

4. Post-Return Procedure

Conclusion 


\section{INTRODUCTION}

This Article comprehensively examines parliamentary habeas corpus proceedings in the reign of James I, the first Stuart king of England.

Parliamentary habeas corpus proceedings-that is, habeas proceedings in a House of Parliament, whether the House of Lords or the House of Commons-generally have been neglected by scholars, even though the journals of both Houses, as well as numerous seventeenth century documents in the Parliamentary Archives (formerly known as the House of Lords Record Office), amply demonstrate that there were a number of parliamentary habeas corpus proceedings during the reigns of the first three Stuart kings of England. Although not well known, these parliamentary habeas proceedings are a fascinating and instructive portion of English legal history.

Perhaps the most interesting of the seventeenth century parliamentary habeas corpus proceedings are those from the reign of King James I, who ruled between 1603 and 1625. It was during James l's reign that it first becomes evident that Parliament was, among other things, a habeas court. It was during James l's reign that we have the first indisputable evidence of writs of habeas corpus being issued by order of and returnable to a House of Parliament for the purpose of inquiring into allegedly unlawful imprisonment-specifically, imprisonment claimed to violate the parliamentary privilege from arrest. It was during James I's reign that the writ of habeas corpus, available in either the House of Lords or the House of Commons, becomes a standard remedy for obtaining release from imprisonment in violation of parliamentary privilege. Approximately fifty parliamentary writs of habeas corpus were issued during the reign, an average of one such writ for each of the fifty months Parliament sat between 1603 and 1625. Amazingly, eighteen original parchment writs of habeas corpus issued in the reign by order of the House of Lords, together with the original parchment returns to those writs, still exist and are in the Parliamentary Archives. Two of the writs of habeas corpus issued in the reign by order of the House of Commons are printed verbatim in the Journal of the House of Commons, as are two returns to habeas writs issued by order of that House during the reign. The most notable parliamentary habeas proceeding in history, involving an imprisoned member of the House of Commons, dates from James I's reign. 
It is for these reasons that the parliamentary habeas proceedings occurring between 1603 and 1625 are the focus of this Article. No longer should the parliamentary habeas proceedings in the time of England's first Stuart monarch be ignored, or their captivating tale go untold.

This Article corrects three misunderstandings reflected in English legal history scholarship. To begin, there has been a mistake as to the number of English courts vested with habeas jurisdiction. Scholarly writings traditionally maintain, without dispute, that the number of English habeas courts was four-the Court of Chancery, and the three common law courts (King's Bench, Common Pleas, and Exchequer). This Article challenges that scholarship by demonstrating that there was a fifth English habeas court. This was the English Parliament itself, which, acting through either of its Houses as a judicial tribunal, would direct that writs of habeas corpus be issued, entertain returns to these writs, conduct habeas corpus proceedings, and grant or deny habeas relief. Moreover, traditional historical scholarship on the topic of habeas corpus and Parliament omits mention of parliamentary habeas proceedings, as if they never occurred. Finally, traditional literature on the history of Parliament as a court of judicature pays scant attention to parliamentary habeas proceedings. Scholarship on the history of English habeas corpus, as well as scholarship on the history of Parliament, is, therefore, defective and in need of revision.

Before outlining the contents of the rest of the Article, this Introduction will first discuss a momentous arrest that took place on the streets of England's greatest city on a spring day not quite a year after James I acceded to the throne, an arrest that ushered in the first parliamentary habeas proceeding of the reign.

Thursday, March 15, 1603/4, ${ }^{1}$ four days before the sitting of the High Court of Parliament, ${ }^{2}$ was a festive occasion in London. On that

${ }^{1}$ During the seventeenth century, the Old Style calendar (under which New Year's Day occurs on March 25) was in effect in England. The New Style calendar (under which New Year's Day is on January 1) did not take effect in England until 1752. It is now customary for scholars, when denoting the year of any event in seventeenth century England occurring between January 1 and March 25 under the Old Style calendar, to set forth the Old Style year date, followed by a forward slash or a hyphen and then the final numeral of the New Style year date. Generally, this customary practice is followed in this Article. Elizabeth I, James I's immediate predecessor, died on March 22,1602/3, ending the Elizabethan era. That same date marked the accession of James I, initiating the twenty-two year Jacobean era. At the time of Sir Thomas Shirley's arrest, therefore, James I had occupied the throne of England for a week less than a year. 
day amidst pomp and pageantry James I made a solemn entry into and a formal progress through London. ${ }^{3}$ Also on that day Sir Thomas Shirley, ${ }^{4}$ a member of the House of Commons riding in a cavalcade

It should also be noted that in the seventeenth century, the O.S. calendar was ten days behind the N.S. calendar. Thursday, March 15, 1603/4 was, therefore, Thursday, March 25, 1604 under the N.S. calendar.

${ }^{2}$ In the seventeenth century, more than at any time before or since, it was accepted practice to refer to Parliament as the High Court of Parliament. See infra notes 17, 21-23 and accompanying text.

${ }^{3}$ For contemporary tracts describing the triumphant arches and the ornate inscribed pegmas erected for the occasion, as well as the joyous celebrations and the elaborate ceremonies that took place that day, see Thomas Dekker, The Magnificent Entertainment Given to King James, and Queene [sic] Anne His Wife, and Henry Frederick, the Prince, Upon the Day of His Majesty's Triumphant Passage (from the Tower) through his Honorable Citie [sic] (and Chamber) of London, Being the 15th Day of March, 1603-4, in 1 John Nichols, The Progresses, Processions, and MAgNificent Festivities of KIng JaMes the FirSt 337, 337-76 (photo. reprint N.Y., Burt Franklin n.d.) (1828); [Ben Johnson,] King James's Royal and Magnificent Entertainment Through His Honourable City of London, Thursday, the 15th of March, 1603-4, in 1 John Nichols, The Progresses, Processions, ano Magnificent Festivities of KING JAMES THE FIRST 377, 377-401 (photo. reprint N.Y., Burt Franklin n.d.) (1828). See also G.P.V. AKRIGG, Jacobean PAGeANT 30-33 (1962) (describing the spectacle, oratory, and music of James I's procession through London); CLARA AND HARDY StEEholm, James I of ENGland: The WISESt Fool in Christendom 277-79 (1938) (same).

The king's grand entrance into and glorious procession through London, not quite a year after his accession to the crown, "was delayed pageantry from the previous year. .. . [T] This was because of the presence of the plague in London." Christopher Lee, 1603: The Death of Elizabeth I, the Return of the Black Plague, the Rise of Shakespeare, Piracy, Witchcraft, and the BirTh of the Stuart Era 158 (2003). In 1603 over 37,000 persons (seventeen percent of the city's population) died of the plague in London. Id. at 192.

${ }^{4}$ Knighted by Elizabeth I in 1573, Sir Thomas Shirley (c.1542-1612), whose last name was sometimes spelled "Sherley" or "Shurley," was a legendary Elizabethan and Jacobean courtier and politician whose exciting life, astonishingly, was surpassed in thrills by the lives of his three sons-Thomas the younger (1564-1633/4), Anthony (1565-1636?), and Robert (c.1581-1628), all adventurers and world travelers. Thomas the younger was a travel writer, a pirate, and an acquaintance of the Shah of Persia, and was once held prisoner by the Turks in Constantinople. Himself once imprisoned in Moscow by decree of Czar Boris Godunov, Anthony was a diplomat, a secret agent, and an acquaintance not only of the Persian Shah, but also of the Doge of Venice, Pope Clement VIII, and Rudolf II, the Holy Roman Emperor (who made Anthony a count palatine). Robert was an acquaintance of the Shah, Polish King Sigismund III, Spanish King Philip III, and Pope Paul V (who made Robert a count of the Lateran and a chamberlain of honor). The father and his three sons all have entries in 50 Oxford Dictionary of NaTiOnal BIOGRAPHY (H.C.G. Matthew \& Brian Harrison eds., 2004). See id. at 315-17 (Thomas), 317-18 (Thomas the younger), 312-15 (Anthony), 399-401 (Robert). For a comprehensive inter- 
forming part of James l's royal procession, was stopped, arrested, and conveyed a prisoner under guard to the Wood Street Compter prison (from which Shirley was soon transferred to the Fleet prison). The arrest was made pursuant to civil arrest process procured by a goldsmith who, claiming he was owed money for a debt that had not been paid, had successfully sued Shirley in a common law court and obtained a monetary civil judgment. The arrest led to the memorable case of In re Sir Thomas Shirley, ${ }^{5}$ a parliamentary habeas corpus proceeding in the House of Commons and the first of more than forty habeas corpus proceedings litigated in the House of Lords or the House of Commons of the High Court of Parliament during the reign of James $\mathrm{I}^{6}$

woven account of the engrossing lives of Shirley and his amazing sons, see D.W. Davies, Elizabethan Errants: The Strange Fortunes of Sir Thomas Sherley [sic] and His THREE SONS (1967).

For a summary of Sir Thomas Shirley's career as a member of the House of Commons, to which he was elected five times, see 3 P.W. HASKER, THE HISTORY OF PARLIAMENT: THE HOUSE OF COMMONS 1558-1603, at 375-76 (1981).

${ }^{5}$ In re Sir Thomas Shirley (H.C. 1603/4, 1604), in (1) 1 H.C.Jour. 149, 155, 167$68,171,200,202-03,204-05,205-06,206-07,208,209-10,210-11,211,213,215$, and (2) 1 HATSELL 157-60.

For more on this remarkable case, see Josh Chavetz, Democracy's Privileged Few: Legislative Privilege and Democratic norms in the British and American Constitutions 29-30, 195-96 (2007); Erskine May's Treatise on The Law, Privileges, Proceedings and Usage of Parliament 94-95 (Barnett Cocks ed., 18th ed. 1971); 5 Parliamentary or Constitutional History of England 113-15 (London, Thomas Osborne, 1751); 1 THE Parlamentary History of England From the Earlest Period to the Year 1803, at 102842 (London, T.C. Hansard, 1806); CarL WittKe, The History of English Parlamentary PrIVILEG 92-94 (1921); G.W. Prothero, The Parliamentary Privilege of Freedom From Arrest, and Sir Thomas Shirley's Case, 1604, 8 ENG. HIST. Rev. 733 (1893). Commentary on the Shirley case usually focuses on issues of parliamentary privilege and rarely is concerned with the habeas aspects of the case.

${ }^{6} \mathrm{~A}$ habeas corpus proceeding (or habeas corpus case) is, of course, a judicial proceeding in which allegedly unlawful imprisonment is challenged and habeas relief from the imprisonment is sought. Once the proceeding is instituted, the habeas court inquires into whether the imprisonment complained of is lawful. If the imprisonment is found by the habeas court to be lawful, the imprisoned person remains in custody. If the habeas court determines that the imprisonment is unlawful, the traditional form of relief granted consists of discharge from custody. Issuance of an actual writ of habeas corpus-a court order, in a prescribed form, requiring that the imprisoned person be brought into court and an explanation for the imprisonment provided-is not mandatory in every habeas case.

A habeas corpus proceeding in the High Court of Parliament was a judicial proceeding in either the House of Lords or the House of Commons where that House, after having been notified by written petition or otherwise that a person 
Although the seizure and detention of Shirley plainly violated the parliamentary privilege of freedom from arrest, ${ }^{7}$ it took the issuance, by order of the House of Commons, of four writs of habeas corpus ${ }^{8}-$ as well as the enactment of two private statutes ${ }^{9}$ and the imprisonment, for contempt of the House of Commons, of the warden of the Fleet prison (who for several days of his confinement was shut up in Little Ease, a cramped, foul, filthy dungeon cell in the Tower of London ${ }^{10}$ )-before the House finally secured Shirley's release from the Fleet prison two months after his arrest. ${ }^{11}$

was allegedly unlawfully imprisoned, authorized issuance of a writ of habeas corpus for the purpose of inquiring into the legality of the imprisonment. In the reign of James I this authorization typically consisted of approval by the House of an order directing that a writ of habeas corpus be issued to bring the imprisoned person before the House. During that reign such authorization is known to have resulted in the actual issuance of at least one writ of habeas corpus in each of the habeas proceedings in the House of Lords and in all but one of the habeas proceedings in the House of Commons.

The only type of unlawful imprisonment a House of the High Court of Parliament would inquire into by habeas corpus during the reign of James I was confinement in violation of the parliamentary privilege from arrest.

${ }^{7}$ The parliamentary freedom from arrest, which then protected not only members of the House of Lords and members of the House of Commons but also their servants, is discussed infra at notes 24-30 and accompanying text.

${ }^{8}$ See infra note 128 and accompanying text.

${ }^{9}$ These statutes, which were not published in the official compilations of the Acts of Parliament, were designed to permit Shirley to be sued by his debtors after the current parliamentary session ended, and to immunize the warden of the Fleet prison from liability for releasing Shirley. For the text and a discussion of both statutes, see G.W. Prothero, The Parliamentary Privilege of Freedom From Arrest, and Sir Thomas Shirley's Case, 1604, 8 ENG. HIST. REv. 733 (1893).

${ }^{10}$ For proceedings in the House of Commons relating to the Fleet warden's imprisonment in Little Ease, see 1 H.C.Jour. 207 (May 11, 1604) (because warden refuses to deliver Sir Thomas Shirley, he is "committed to the Prison called Little Ease, within the Tower"); 1 H.C.Jour. 208 (May 12, 1604) (motion to appoint "certain Gentlemen of the House" who are to repair to the Tower and inform themselves whether the warden has been committed to Little Ease); 1 H.C.Jour. 209 (May 14, 1604) (report of gentlemen who repaired to the Tower in inquire into the warden's restraint in Little Ease, a "Place" of "Loathsomeness"); 1 H.C.Jour. 211 (May 15, 1604) (letter to House Speaker from warden, written from Little Ease); 1 H.C.Jour. 211 (May 16, 1604) (warden to be delivered out of Little Ease, but to remain a prisoner in the Tower).

One scholar calls Little Ease a "particularly unsavory dungeon ...." Johann P. Sommerville, Parliament, Privilege, and the Liberties of the Subject, in PARLIAMENT and LiberTy From the Reign of Elizabeth to the English CIVIL WaR 61 (J.H. Hexter ed., 1992). Little Ease "was in truth one of the most dreadful dungeons in Europe ..." Richard DAVEY, TOWER OF LONDON 18 (1910). Little Ease was located beneath the 
The House of Commons' resounding success in securing Shirley's discharge from custody was a "triumph of Parliament" and a "famous victory" for the House, ${ }^{12}$ as well as "a landmark in the history of parliamentary privilege." ${ }^{13}$ It was also a habeas corpus milestone. For the first time a House of the High Court of Parliament had used a writ of habeas corpus, ordered issued by that House itself and

ground floor of the White Tower in what has been described as "a crypt beneath a crypt," 1 WILLIAM HEPWORTH DIXON, HER MAJESTY'S TOWER 26 (1901), or a "sub-crypt," George Younghusband, The TOWER of London 125 (1926). "Little Ease was a cell so small that a prisoner could not fully stretch out in any direction. 'He was obliged to sit in a squatting position and was kept imprisoned there." Josh Chavetz, Executive Branch Contempt of Congress, 76 U. CHI. L. Rev. 1083, 1096 n.73 (2009) (citation omitted); see also 6 Notes AND Queries $2 d 345$ (Oct. 30, 1858) ("[Little Ease] was of so small dimensions and so constructed that the prisoner could neither stand, sit, nor lie at full length. He was compelled to draw himself up in a squatting position ..."). Little Ease was entered through a "formidable iron-studded door ... with its ingenious system of locks and bolts ..." ARTHUR POYSER, THE TOWER OF LONDON 118 (1908). The cell was "without light or ventilation," and its floor was "rough earth." R.J. MINney, THE TOWER OF LONDON 16 (1970).

${ }^{11}$ Shirley was released and took his seat in the House of Commons on May 15, 1604. 1 H.C.JouR. 210 (May 15, 1604). Shirley was therefore incarcerated from March 15 to May 15.

Not long after Shirley's release (the exact date is unknown) the Privilege of Parliament Act, 1603, 1 Jac. 1, c. 13 (Eng.), was enacted. (The statute received the Royal Assent in 1604, not 1603, but because Acts of Parliament used to take effect from the first day of the parliamentary session, this is the short title given the statute by the Statute Law Reform Act, 1948, 11 \& 12 Geo. 6, c. 62 sch. 2 (Eng.).) In addition to "recogniz[ing] the privilege of freedom from arrest, the right of either House of Parliament to set a privileged person at liberty, and the right to punish those who make or procure arrests [that violate parliamentary privilege]," the Privilege of Parliament Act also "enacted that after such time as the privilege of that session in which privilege is granted shall cease, parties may sue forth and execute a new writ; and that no sheriff, etc., from whose arrest or custody persons shall be delivered by privilege, shall be chargeable with any action." ERSKINE MAY's TREATISE on The Law, Privileges, Proceedings and Usage of Parliament 95 (Barnett Cocks ed., 18th ed. 1971).

12 D.W. Davies, Elizabethan Errants: The Strange Fortunes of SiR Thomas Sherley [sic] and His Three Sons 189 (1967). See also Josh Chavetz, Democracr's Privileged Few: Legislative Privilege and Democratic norms in the British and American Constitutions 30 (2007) (in effecting Shirley's release by itself, "[t]he House of Commons had won an important victory"); CARL WittKe, The History of English Parliamentary Privilege 94 (1921) ("The lower house won a great victory in principle."); G.W. Prothero, The Parliamentary Privilege of Freedom From Arrest, and Sir Thomas Shirley's Case, 1604, 8 ENG. HIST. REv. 733, 734, 737 (1893) ("Victory remained with the house of commons .... [ [ ]n the end the commons had won a complete victory.").

13 3 P.W. HASLer, THe HOUSE OF COMMONs 1558-1603, at 376 (1981). 
returnable to that House, to compel the release of a person imprisoned in violation of parliamentary privilege. ${ }^{14} \mathrm{It}$ was now firmly established that the House of Commons possessed "the right to release imprisoned members [and other privileged persons] by means of their own officers, without any interference on the part of the crown or the law-courts." 15 That the more prestigious House of Lords possessed equivalent power could hardly be doubted. ${ }^{16}$ Before the end of the second year of the reign of James I, therefore, if not earlier, it had become firmly accepted that in a parliamentary judicial proceeding the remedy of the writ of habeas corpus was an appropriate procedure for obtaining the release of someone im-

${ }^{14}$ Although there were numerous pre-James I parliamentary proceedings involving claims that a member or a servant was now or recently had been imprisoned in violation of the parliamentary privilege from arrest, in none of them did a House of Parliament, acting on its own, use the writ of habeas corpus to force the release of a person detained in violation of the privilege. For examples of these pre-1603 proceedings, which were not habeas corpus proceedings, see SELECT Statutes and Other Constitutional Documents Illustrative of the Reigns of Elizabeth and James I 126-29 (G.W. Prothero ed., 1913); Select Documents of English Constitutional History 191-93, 196-97, 261-64 (George Burton Adams \& H. Morse Stephens eds., 1924); see also In re William Vaughn (H.L. 1601), in 2 H.L.Jour. 238, 239, 240, 241 (servant of member of House of Lords, imprisoned in violation of parliamentary privilege, ordered discharged from custody by writ of privilege rather than writ of habeas corpus). For discussion of how the parliamentary privilege from arrest was enforced prior to the reign of James I, see ERSKINe MaY's TrEatise on THE LAW, PriviLeges, Proceedings and Usage of Parliament 91-94 (Barnett Cocks ed., 18th ed. 1971); Carl Wittke, The History of English Parlaamentary Privilege 32-37 (1921); Robert J. Reinstein \& Harvey A. Silverglate, Legislative Privilege and the Separation of Powers, 86 HARV. L. REv. 1113, 1123 n.48 (1973).

The first use of the writ of habeas corpus in the High Court of Parliament to inquire into imprisonment allegedly violative of parliamentary privilege appears to have been in 1593, when the House of Commons, at the suggestion of Sir Edward Coke (then Speaker of the House of Commons), ordered issuance of the writ in regard to a member who had been arrested under civil arrest process for debt on the morning of his election. See J.E. Neale, Elizabeth I and Her Parlaments 1584-1601, at 313-16 (1958). Relief was ultimately denied, however. Id. at 318. Moreover, the writ was returnable not to the House of Commons, but to the Chancery. Id. at 317. For additional information on the 1593 episode, see 1 P.W. HASKER, THE HISTORY OF Parliament: House of Commons, 1558-1603, at 623-25 (1981); 2 id. at 125-26.

15 G.W. Prothero, The Parliamentary Privilege of Freedom From Arrest, and Sir Thomas Shirley's Case, 1604, 8 Eng. HIST. Rev. 733, 734 (1893).

${ }^{16}$ In fact, in 1604, the second year of the new reign, six habeas corpus cases were litigated in the House of Lords, and in at least half these cases habeas relief was granted. See infra Appendix 1, Part A. 
prisoned in violation of parliamentary privilege. Moreover, the stage was set for additional habeas proceedings in the House of Commons or the House of Lords in future instances of infringement of the privilege.

Part I of the Article provides answers to questions concerning the historical context of the Jacobean parliamentary habeas proceedings. What was the origin and significance of the term High Court of Parliament? What was scope of the parliamentary privilege from arrest, the violation of which could lead to the granting of habeas corpus relief by a House of the High Court of Parliament? What was the civil arrest system in effect in seventeenth century England-a system which made it likely that from time to time the parliamentary privilege against arrest would be violated and the parliamentary habeas remedy thereupon invoked? What other parliamentary remedies, apart from habeas corpus, were available to deal with infringements of the arrest privilege? And what were the contours of the parliamentary habeas corpus remedy itself?

Parts II and III of the Article are concerned with the habeas corpus jurisdiction and practices of the Jacobean High Court of Parliament, and are the heart of the Article. They demonstrate beyond doubt that in the Jacobean era the High Court of Parliament at times functioned as the High Habeas Court of Parliament. Part II provides an in-depth account of the habeas corpus proceedings in the House of Lords of the High Court of Parliament in the reign of James I, while Part III does the same for the habeas corpus proceedings in the House of Commons of the High Court of Parliament during the reign.

The Article concludes with a comprehensive explanation of the revisions this work requires in our understanding of English legal history. First, to the traditional list of English courts with habeas jurisdiction must be added the High Court of Parliament. The Court of Chancery and the three common law courts were not the only English courts with habeas jurisdiction. Second, to the traditional categories of scholarship on the topic of Parliament and the writ of habeas corpus an entirely new category must be added: scholarship on habeas corpus proceedings in Parliament itself. Third, to the traditional categories of scholarship on the High Court of Parliament must be added an entirely new category: scholarship on the High Court of Parliament as a habeas court. 


\section{HABEAS CORPUS, PRIVILEGE, AND THE HIGH COURT OF PARLIAMENT IN THE REIGN OF JAMES I}

\section{A. THE HIGH COURT OF PARLIAMENT}

In England during the Jacobean period-and, indeed throughout the seventeenth century-Parliament was commonly known as the High Court of Parliament. ${ }^{17}$

${ }^{17}$ See infra notes 21-23 and accompanying text.

The term High Court of Parliament must be put in proper historical perspective. The term meant that Parliament was a court of judicature. The term did not mean that Parliament was exclusively a court of judicature. "It is a mistake to think of ... Parliament as a court in our modern sense ..." JefFrey Goldsworthy, The Sovereignty of Parliament: History and Philosophy 40 (1999). Rather, the term meant that Parliament was a body that exercised judicial functions as well as legislative ones. "No one believed Parliament was a court in a radical sense that would truly deny or repress its legislative character ..." Charles M. Gray, Parliament, Liberty, and the Law, in Parliament and Liberty From the Reign of Elizabeth to the English Civil War 182 (J.H. Hexter ed., 1992). "When we speak of Parliament as a 'court of justice' and designate its actions 'judicial,' it will be remembered that 'court' and 'judicial' are not to be used in their modern definite sense.... [W]e [must] consider Parliament as a 'court of justice' which in addition exercised other distinct powers, or as a legislature with an addendum of other duties." Charles Howard Mcllwain, The High Court of Parliament and Its Supremacy 119 (1910).

It must also be understood that not only was the bicameral High Court of Parliament a court of judicature, but, in addition, each of the two constituent Houses of the High Court of Parliament was a court of judicature by itself. The House of Lords was a court, and the House of Commons was a court. It was not necessary that a judicial proceeding be tried or heard in both Houses in order for it to be deemed a judicial proceeding in the High Court of Parliament. A judicial proceeding in either the House of Lords or the House of Commons was to all intents and purposes a judicial proceeding in the High Court of Parliament. See SIR EDWARD CoKE, THE Fourth PART OF THE Institutes OF THE LAWS OF England 23 (London, M. Flesher 1648) ("And it is to be known, that the Lords in their House have power of Judicature, and the Commons in their House have power of Judicature, and both Houses together have power of Judicature."). See also J.E. Neale, Elizabeth I and Her ParliaMENTS 1584-1601, at 317 (1958) (in 1593 an eminent lawyer and member of the House of Commons made a speech to the House in which he said: "This court [the House of Commons] for the dignity and highness of it, hath privileges as all other courts have; and as it is above all other courts, so hath it privileges above any court; and as it hath privilege and jurisdiction, so hath it also coercion and compulsion, otherwise the jurisdiction in a court is nothing ..."). The habeas corpus proceedings in the House of Commons were, therefore, ipso facto, habeas corpus proceedings in the High Court of Parliament. Similarly, the habeas proceedings in the House of Lords were also necessarily habeas proceedings in the High Court of Parliament. The habeas jurisdiction of the High Court of Parliament extended to and was exercised separately by each of its Houses. 


\section{Parliament was first referred to as the High Court of Parliament} in the fourteenth century. ${ }^{18}$ In the fifteenth century, the term High

The view that the House of Lords was a court of judicature remained authoritative until the early twenty-first century when legislation stripped the House of Lords of the appellate jurisdiction which made it the supreme court of the realm, but the notion that the House of Commons was a court began to wane starting around 1700 . As late as the nineteenth century, however, there were still commentators stoutly maintaining that the House of Commons was a court-indeed, a court of record. See, e.g., S.A. Ferrall, An Exposition of the Law of ParlaAment as it Relates to the Power and Privileges of the Commons' house 114 (London, S. Sweet 1837) ("The House of Commons must then possess ... every species of authority that the highest ordinary court of record in the kingdom is clothed with. ... and being the highest court of record, its acts are not subject to the revision of any

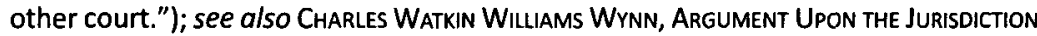
of the House of Commons to Commit in CASes of Privilege 3, 5 (London, Cox, Son, and Baylis 1810) ("Each House is a chamber of the High Court of Parliament ... The House of Commons is an original and permanent part of the highest judicature in the country, and, as a Chamber of Parliament, combines the magisterial and judicial functions with those of a permanent and universal inquest.").

${ }^{18}$ A.L. Brown, The Governance of Late Medieval England 1272-1461, at 233 (1989) ("The phrase 'the High Court of Parliament' began to be used in the 1380s"). One of the earliest descriptions of Parliament as a "High Court" occurred in 1384, when the Chancellor, Michael de la Pole, spoke of "le pluis haute Courte del Roialme." 3 Rotuli Parlaamentorum; ut et Petitions, et Placita in Parliamento 169 (London, 176677); see also S.B. Chrimes, English Constitutional Ideas in the Fifteenth Century 71 (1936) ("it is hard to find any evidence that the word 'court' was actually and explicitly applied to parliament until after $1380^{\prime \prime}$ ).

The term High Court of Parliament hearkens back to the thirteenth century, when Parliament had not yet divided into two Houses and its functions were as much judicial as they were legislative. See Kilbourn v. Thompson, 103 U.S. 168, $183-86(1880)$.

With respect to Parliament before or after it split into two Houses around the middle of the fourteenth century, "[h]ardly anyone will deny the eminently judicial cast of Parliament in the middle ages..." Charles Howard Mcliwain, The High Court of Parliament and Its Supremacy 120 (1910); see also A.F. Pollard, The Evolution of ParlaAment 35, 36 (2d ed. 1968) ("Mainly ... the business of Edward l's parliaments is to deal out justice. ... Primarily Parliament [was then] a high court of justice."); J.G. Edwards, "Justice" in Early English Parliaments, 27 BULL. INST. HIST. RESEARCH 35, 35, 53 (1954) (a prominent feature of historical studies of Parliament in the thirteenth and fourteenth centuries has been the emphasis placed upon the role of justice in the business of Parliament; "Parliament was a high court not merely because it was judicially above other courts, but also because it was more than a judicial court; it was an omnicompetent organ at the summit of lay affairs in England"); H.G. Richardson \& George Sayles, The Parliaments of Edward III, 9 BuLL. INST. HIST. RESEARCH 1, 2 (1931) ("The dispensation of justice remained in the eyes of the people, if not in the eyes of the king and his ministers, the prime purpose of parliament" in the reign of Edward III); H.G. Richardson \& George Sayles, The Early Records of the English Parliaments I-The Parliaments of Edward II, 6 


\section{Court of Parliament "came into wider use,"19 and in the sixteenth century the term enjoyed a "continued vogue."20}

BULL. INST. HIST. RESEARCH 71, 78 (1928) (in the reign of Edward II, as in the reign of Edward I, "parliaments are of one kind only and the essence of them is the dispensation of justice"); H.G. Richardson \& George Sayles, The Early Records of the English Parliaments I-The Parliaments of Edward I, 5 BuLL. INST. HIST. RESEARCH 129, 133 (1928) ("the essence of [the Parliaments of Edward I] is the dispensing of justice").

19 A.L. Brown, The Governance of Late Medieval England 1272-1461, at 233 (1989). Thus, in February 1454, the common law judges, appearing before Parliament to express their views on the parliamentary privilege from arrest, referred three times to "this high Court of Parlement [sic]," 5 Rotul PARLIAMENTORUM; UT ET PETITIONS, ET PLACITA IN PARLIAMENTO 239-40 (London, 1766-77); and throughout the fifteenth century the House of Commons would make reference to the "high court of parliament ... not infrequent[ly]." S.B. Chrimes, ENGlish Constitutional IDEAS IN THE FifteentH Century 72 (1936). In a 1459 case, one of the common law judges announced: "[T]he court of parliament is the highest court the king has ..." KENNETH PICKTHORN, EARLY TUDOR GOVERNMENT: HeNRY VII 133 n.1 (1967). In 1483 the Chancellor, John Russell, drafted a speech to be delivered to an intended Parliament, which he called "the kynges most hygh and souerayne courte," A.R. Myers, Parliament, 1422-1509, in The English Parliament in the Middle Ages 149 (R.G. Davies \& J.H. Denton eds., 1981).

For additional information on use of the term High Court of Parliament in fifteenth century England, see A.R. Myers, Parliament, 1422-1509, in THE ENGLISH PARlament in the Middle Ages 149-53 (R.G. Davies \& J.H. Denton eds., 1981); S.B. Chrimes, English Constitutional Ideas in the Fifteenth Century 71-75 (1936).

${ }^{20}$ S.B. Chrimes, English Constitutional Ideas in the Fifteenth Century 75 (1936). Thus, Edward VI's 1547 commission granting the Duke of Somerset precedence in the seating arrangements in the chamber of the House of Lords referred to "Our High Court of Parliament," 1 H.L.Jour. 293 (Nov. 4, 1547); the authors of perhaps the most important tract of Elizabethan Puritanism, An Admonition to the Parliament, published anonymously in 1572, requested therein that they be allowed to defend themselves "in this High Court of Parliament," Select Statutes and Other Constitutional Documents ILLUSTRATIVE of THE REIGNS OF ElizABETH AND James I 199 (G.W. Prothero ed., 1913); in 1584, one James Diggs, seeking to avoid punishment for contempt of the House of Lords, filed with that body a document (entitled in part "The Humble Submission of James Diggs unto the High Court of Parliament ...") which three times described the House of Lords as being part of "this High Court of Parliament," 2 H.L.Jour. $73-74$ (Dec. 15, 1584); in WillaAm HarRison, The Description of England 27 (Georges Edelen ed., 1968) (1587), the author referred to "the three estates of the realm in the High Court of Parliament;" and "in 1593, the Speaker of the House of Commons [Sir Edward Coke] began the closing speech of the session with these words, 'The high court of parliament[,] most high and mighty prince, is the greatest and most ancient court within your realm' ..." CARL WITTKE, THE HISTORY OF ENGLISH Parliamentary Privilege 94 n.9 (1921).

Before the end of the sixteenth century Parliament had begun referring to itself in statutes as "the high court of parliament," as seen in the preamble to the Error from the Queen's Bench Act, 27 Eliz. 1, c. 8 (1585) (Eng.). See also Trewynard's 
In the seventeenth century the practice of describing Parliament as the High Court of Parliament reached its zenith. ${ }^{21}$ In the 1600 s in England, Parliament was the High Court of Parliament. ${ }^{22}$ And at no

Case, 73 Eng. Rep. 132, 133 (K.B. 1545), where it was "conclude[d] that this court of parliament is the most high court, and hath more privileges than any other court in the kingdom."

In William Shakespeare, The Second Part of King Henry IV, act 5, sc. 2, written between 1596 and 1599, Henry V says: "Now call we our high court of parliament."

21 "Contemporaries clearly recognised [sic] Parliament's identity as a court and referred frequently to the "High Court of Parliament."' DAVID L. SMITH, THE STUART PARLIAMENTS 1603-1689, at 34 (1999); see also Charles M. Gray, Parliament, Liberty, and the Law, in Parlaament and Liberty From the Reign of Elizabeth to the English CiviL WAR 182 (J.H. Hexter ed., 1992) (in seventeenth century England, "Parliament was regularly called a court, the top court, the high court of Parliament."); Eric Schnapper, The Parliament of Wonders, 84 Colum. L. Rev. 1665, 1671 (1984) (book review) (in the seventeenth century, Parliament "was still referred to as 'the High Court of Parliament"').

${ }^{22}$ Memorably, the first chapter of SIR EDWARD COKE, THE FourTh PART OF THE INSTHTUTES OF THE LAWS OF ENGLAND (London, M. Flesher 1648), first published in 1644, is entitled "Of the High and most Honourable Court of Parliament," id. at 1; also in 1644 , in London, Roger Williams published a pamphlet entitled in part "Queries of highest consideration," which states on the title page that it is "[i]n all humble reverence presented to the view of the High Court of Parliament," see MiCHAEL FARRIS, From TYNDALE To MADISON 477 (2007); and the title page of the anonymous THE Privileges and Practice of Parliaments in England Collected Out of the Common laws OF THIS LAND (London, 1680), announces that the work is "Commended to the High Court of Parliament."

Numerous law review publications, accessible via Westlaw, quote seventeenth century English documents which use the term High Court of Parliament. For examples, see Mark Rose, The Public Sphere and the Emergence of Copyright: Areopagitica, the Stationers' Company, and the Statute of Anne, 12 TUL. J. TECH. \& INTELL. PROP. 123, 133 n.37 (2009) (quoting 1643 document); R.H. Hemholtz, Natural Law and Human Rights in English Law: From Bracton to Blackstone, 3 AVE MARIA L. Rev. 1, 9 n.55 (2005) (quoting 1644 document); Ulrike Muessig, Née Seif, The Common Legal Tradition of a Court Established by Law: Historical Foundations of Art. 6 Para. 1 European Convention on Human Rights, 47 AM. J. LEGAL HIST. 161, 171 n.73 (2005) (quoting 1642 document); Raymond Astbury, A Loser's Ingenuity, 15 YALE J.L. \& HUMAN. 435, 440 (2003) (book review) (quoting 1679 document); Louise Halper, Measure for Measure: Law, Prerogative, Subversion, 13 CaRdozo Stud. L. \& Literature 221, 234 (2001) (quoting 1604 document); Steve Bachmann, The Politics of the First Amendment, 6 CARDOZO ARTS \& ENT. L.J. 327, 338 (1988) (quoting 1647 document).

In the eighteenth century, as Parliament's legislative and political policy-making activities came to predominate, and as the House of Commons functioned less and less as a judicial tribunal, the term High Court of Parliament increasingly appeared anachronistic and use of the term gradually declined. It did not disappear, however. See, e.g., Thornagh Gurdon, The History of the High Court of Parlament (London, 


\section{time during that century was the term High Court of Parliament} more commonly used by both a reigning Sovereign and his Parliament than during the twenty-two years of the Jacobean period. ${ }^{23}$

Macmillan 1731); William Petrt, Jus Parlamentarium: Or, the Ancient Power, Jurisoiction, Rights and Liberties of the Most High Court of Parliament Revived and Asserted (London, 1739).

For examples of law review publications, available on Westlaw, which quote eighteenth century English documents using the term High Court of Parliament, see Emily Kadens, The Last Bankrupt Hanged: Balancing Incentives in the Development of Bankruptcy Law, 59 DuKE L.J. 1229, 1234 n.21 (2010) (quoting ca. 1706 document); Emily Kadens, The Pitkin Affair: A Study of Fraud in Early English Bankruptcy, 84 Am. BANKR. L.J. 483, 533 (2010) (quoting 1707 document); Philip A. Hamburger, Revolution and Judicial Review: Chief Justice Holt's Opinion in City of London v. Wood, 94 CoLUM. L. REv. 2091, 2140 (1994) (quoting 1702 document).

In his great treatise, Blackstone used the term High Court of Parliament four times. 4 William Blackstone, Commentaries on the Laws of England 82, 256 (photo. reprint 1966) (Oxford, Clarendon 1769); 1 WILLIAM BLACKSTONE, COMMENTARIES ON THE LAWS OF ENGLAND 158, 159 (photo. reprint 1966) (Oxford, Clarendon 1765).

In the nineteenth century, the practice of describing Parliament as the High Court of Parliament nearly died out, although some scholars clung to the practice, at least occasionally, see, e.g., 1 WillaAm R. ANSON, the LAW AND CUSTOM OF THE CONStitution 299 (Oxford, Clarendon 1886); A.V. DiceY, INTRODUCtion to THE Study OF THE LAW OF THE Constitution 184, 302, 343, 366, 377 (3d ed. London, Macmillan 1889); Eoward A. Freeman, The Growth of the English Constitution from the Earliest Times 115,120 (2d ed. London, Macmillan 1873); Francis Palgrave, An Essay Upon the Original AUtHORITY OF THE KING's COUNCIL 22 (1834), as did some English courts, see, e.g., R., on the Prosecution of Gregory v. Allen, 121 Eng. Rep. 929, 932 (Q.B. 1862); Kielley v. Carson, 13 Eng. Rep. 225, 235 (P.C. 1842); Burdett v. Abbot, 104 Eng. Rep. 501, 553, 555 (K.B. 1811) (Ellenborough, C.J.), and even Parliament itself, see, e.g., Metropolitan Police Act, 1839, 2 \& 3 Vict. c. 47, § 52 (Eng.) (“Commissioners of Police ... shall give Directions to the Constables for preventing any Obstruction of the Thoroughfares in the immediate Neighbourhood of . . the High Court of Parliament").

During the twentieth century, use of the term High Court of Parliament, with some exceptions, tended to be confined to historical writings. See, e.g., Charles Howard Mcliwain, The High Court of Parliament and Its Supremacy (1910); J. Stoddart Flemion, Slow Process, Due Process, and the High Court of Parliament: A Reinterpretation of the Revival of Judicature in the House of Lords in 1621, 17 HIST. J. 3 (1974). The second chapter of A.F. Pollard, The Evolution of Parliament ( $2 \mathrm{~d}$ ed. 1968), is entitled "The High Court of Parliament," id. at 20, and the twelfth chapter of A.T. CARTER, A History of ENGLISH Legal InStITUtions (photo. reprint 1986) (1902), is entitled "The High Court of Parliament, the House of Lords, and the Court of the Lord High Steward," id. at 96. See also AN ENCYCLOPEDIA OF PARLIAMENT 349 (Norman Wilding \& Philip Laundy eds., 4th ed. 1971) (the expression High Court of Pariiament "now refers to the legislature, but is a reminder that the British Parliament ... was ... a court-the highest court in the land").

${ }^{23}$ Thus, immediately after James I delivered his first Royal Speech to Parliament, the Speaker of the House of Commons replied with a speech which referred to 
It is both historically accurate and legally correct, therefore, to assert that the habeas corpus proceedings in the House of Lords or the House of Commons in Jacobean England were heard by the court of judicature then known as the High Court of Parliament, and that the High Court of Parliament was a habeas court insofar as either of its Houses entertained habeas proceedings.

\section{B. THE PARLIAMENTARY PRIVILEGE OF FREEDOM FROM ARREST}

In seventeenth century England the parliamentary privilege of freedom from arrest was long-standing and well-established. ${ }^{24}$ The privilege did not apply to criminal arrests (defined as arrests for

\footnotetext{
"Your Majesty's Great and High Court of Parliament," 1 H.C.Jour. 146 (Mar. 22, 1603/4); in 1604, the House of Commons remonstrated with James I over the issue of parliamentary privileges, protesting that the king's narrow view of these privileges was "derogatory in the highest degree to ... your Majesty's High Court of Parliament," J.H. Hexter, Parliament, Liberty, and Freedom of Elections, in PARLIAMENT and Liberty From the Reign of Elizabeth to the English Civil War 42 (J.H. Hexter ed., 1992); on November 9, 1605, James I delivered a Royal Speech to Parliament in which he referred to "this high Court of Parliament," KIng James VI AND I: Political WRITINGs 155 (Johann P. Sommerville ed., 1994); and in a 1607 Royal Speech to Parliament James I spoke of "the high Court of Parliament," 1 H.C.Jour. 358 (Mar. 31, 1607). In a 1609 parliamentary speech, James I said that "Parliament is the highest court of justice ..." JefFrey Goldsworthy, The Sovereignty of Parlament: History and PHILOSOPHY 115 n.271 (1999).

${ }^{24}$ The privilege from arrest "has always been considered one of the most important of parliamentary privileges." G.W. Prothero, The Parliamentary Privilege of Freedom From Arrest, and Sir Thomas Shirley's Case, 8 ENG. HIST. REV. 733, 73334 (1893). This privilege "is among the most ancient of Parliament's privileges." josh Chavetz, Democracy's Privileged Few: Legislative Privilege and Democratic Norms in THE BRITISH AND AMERICAN CONSTITUTIONS 111 (2007), and "[t]he earliest known case of the privilege of freedom from arrest [in which a member of Parliament was ordered released from custody] dates from 1340," id. at 112.

"The privilege of freedom from arrest, which appears to be the earliest recorded privilege, originated in royal proclamations stating that all members going to or from Parliament were under the prescriptive protection of the King, who summoned them. In 1290, Edward I decreed that distraints against members of the King's council in time of Parliament were forbidden; and in 1314 Edward II issued writs to stay all actions by assize against members of either house during a session. The first instance in which a breach of this privilege was remedied occurred in 1315, when the Prior of Malton was placed under civil arrest while returning from Parliament. The King declared the arrest to be an act done in contempt of the Crown and gave the prior a right to damages." Robert J. Reinstein \& Harvey A. Silverglate, Legislative Privilege and the Separation of Powers, 86 HARV. L. REV. 1113, 1123 n.48 (1973).
} 
treason, felony, or breach of the peace)..$^{25}$ The privilege protected against civil arrests only. ${ }^{26}$ The privilege did, however, extend not only to members of the Houses of Parliament, but also to the servants of those members. ${ }^{27}$

Not every civil arrest of a parliamentary member or servant violated the privilege of freedom from arrest. The privilege existed only during what was sometimes known as time of privilege. In the House of Lords the duration of the privilege was from the time Parliament was summoned until twenty days after the parliamentary session ended, ${ }^{28}$ whereas in the House of Commons, according to Blackstone,

25 "A brief consideration of the subject of parliamentary privilege in England will, we think, show the source whence the expression 'treason, felony, and breach of the peace' was drawn, and leave no doubt that the words were used in England for the very purpose of excluding all crimes from the operation of the parliamentary privilege, and therefore to leave that privilege to apply only to prosecutions of a civil nature." Williamson v. United States, 207 U.S. 425, 438 (1908). See generally Erskine May's Treatise on The Law, Privileges, Proceedings and Usage of Parlament 75 (C.J. Boulton ed., 21st ed. 1989) ("it has always been recognized that [the] privilege could not be pleaded against criminal offenses, then adequately summed up as treason, felony, and breach of the peace"); 1 WILLIAM BLACKSTONE, COMMENTARIES ON THE LAWS OF ENGLAND 161 (photo. reprint 1966) (Oxford, Clarendon 1765) (parliamentary privilege from arrest "does not hold in crimes of such public malignity as treason, felony, or breach of the peace"); G.W. Prothero, The Parliamentary Privilege of Freedom From Arrest, and Sir Thomas Shirley's Case, 8 ENG. HIST. REv. 733, 733 (1893) (describing the privilege as a "freedom from arrest, except for treason, felony, and breach of the peace").

26 "The privilege of freedom from arrest has always been limited to civil causes, and has not been allowed to interfere with the administration of criminal justice." Thomas Erskine May, Treatise on The Law, Privileges, Proceedings and Usage of Parliament 104 (photo. reprint 1971) (1844); see also Williamson v. United States, 207 U.S. 425, 438 (1908) (in England and America crimes are excluded from the operation of the parliamentary privilege, which applies only to arrests of a civil nature).

${ }^{27}$ See generally A.S. Turberville, The "Protection" of the Servants of Members of Parliament, 42 ENG. HIST. REv. 590 (1927).

The parliamentary privilege from arrest for servants of members of either House of Parliament was abolished in 1770, at which time the privilege was restricted to members only. Parliamentary Privilege Act, 1770, 10 Geo. 3, c. 50, § 3 (Eng.).

${ }^{28} \mathrm{See}$, e.g., 3 H.L.Jour. 417-18 (May 28, 1624) (parliamentary freedom from arrest begins with date of writ of summons for Parliament, and continues 20 days after every session of Parliament). See also In re Sir Edward Osbaldeston (H.L. 1623/4), in 3 H.L.Jour. 261, 264 ("the Privileges of Parliament do begin with the Date of the Writ of Summons . . . and not with the Time of Delivery of the same Writ"). 
the privilege began forty days before the next appointed meeting of Parliament and ended forty days after every prorogation. ${ }^{29}$

Arresting or imprisoning, however, under civil arrest process, a member of either House of Parliament or a servant of a member, in time of Parliament, clearly violated the parliamentary privilege against arrest. In the large majority of the habeas corpus proceedings in the High Court of Parliament in the reign of James I, the alleged violation of the privilege from arrest stemmed from civil arrest process..$^{30}$

\section{THE CIVIL ARREST SYSTEM}

Jacobean England's legal system was a creditor's paradise-and a debtor's horror. For debtors, civil arrest warrants, civil arrests, and civil imprisonment were commonplace. There were noisome debtor's prisons. Imprisonment for debt was not only accepted fact but deemed a positive good.

In seventeenth century England, unlike today, civil arrest process was an integral part of civil procedure. ${ }^{31}$ Civil procedure rules were

291 William Blackstone, Commentaries on the Laws of England 160 (photo. reprint 1966) (Oxford, Clarendon 1765). Other scholars maintain that Blackstone was in error on this point, and that the exact duration of the privilege in the House of Commons was never fixed by that House. See, e.g., Thomas Erskine MaY, Treatise on The Law, Privileges, Proceedings and Usage of Parliament 95 (photo. reprint 1971) (1844) (stating that there are no precedents supporting Blackstone's claim and that the precise duration of the privilege in the House of Commons is "altogether in doubt").

${ }^{30}$ In only three of the habeas cases in the High Court of Parliament in the reign of James I was the imprisonment complained of not attributable to civil arrest process. See infra notes 54, 141-143 and accompanying text. Those three cases were all in the House of Commons. Id.

${ }^{31}$ For overviews of the civil arrest system, see Howard C. Buschman, Jr. \& Arnold L. Mayerson, Civil Arrest and Execution Against the Person, 12 ALB. L. REV. 17, 28 (1948); Richard Ford, Imprisonment for Debt, 25 MICH. L. Rev. 24, 27-28 (1927); Abraham L. Freedman, Imprisonment for Debt, 2 TEMP. L. Q. 330, 347-50 (1928); Nathan Levy, Jr., Mesne Process in Personal Actions at Common Law and the Power Doctrine, 78 YaLE L.J. 52, 59-61 (1968); Eugene J. Morris \& Hilton M. Wiener, Civil Arrest: A Medieval Anachronism, 43 Brook. L. Rev. 383, 384 (1976); Note, Civil Arrest of Fraudulent Debtors: Toward Limiting the Capias Process, 26 RutGers L. REv. 843, 854-56 (1973); Note, Present Status of Execution Against the Body of the Judgment Debtor, 42 lowa L. REv. 306, 306-07 (1957); Comment, Imprisonment for Debt and the Constitution, 1970 LAW \& SOC. ORDER 659, 659-60.

The best law periodical article on the origins and development of common law civil arrest writs in England remains John C. Fox, Process of Imprisonment at Common Law, 39 Law Q. Rev. 46 (1923). 
harsh on civil defendant debtors, ${ }^{32}$ who could be-and frequently were-seized under a civil arrest warrant and imprisoned. ${ }^{33}$ In personal actions, ${ }^{34}$ defendants were subject to arrest and imprisonment prior to trial under a writ of capias ad respondendum, ${ }^{35}$ while defendants against whom a monetary civil judgment had been en-

${ }^{32}$ See Howard C. Buschman, Jr. \& Arnold L. Mayerson, Civil Arrest and Execution Against the Person, 12 ALB. L. REv. 17, 28 (1948) ("The greatest abuses obtained in imprisonment to enforce collection of [civil] judgments."); Eugene J. Morris \& Hilton M. Wiener, Civil Arrest: A Medieval Anachronism, 43 Brook. L. Rev. 383, 384 (1976) (examining harsh attitudes towards debtors at common law in England).

"The prevailing attitude towards debtors was epitomized in a frequently quoted case, Manby v. Scott:

If a man be taken in execution and lie in prison for debt, neither the plaintiff at whose suit he is arrested, nor the sheriff who took him, is bound to find him meat, drink, and clothes; but he must live on his own, or on the charity of others; and if no man will relieve him, let him die in the name of God, says the law; and so say I.

1 Mod. 124, 86 Eng. Rep. 781, 786 (Exch. 1663)." Eugene J. Morris \& Hilton M. Wiener, Civil Arrest: A Medieval Anachronism, 43 Brook. L. Rev. 383, 384 n.10 (1976).

33 "The practice of imprisoning for debt grew to such proportions in England that separate prisons were established for debtors. The deplorable conditions of these prisons were written about by protest writers ..." Comment, Imprisonment for Debt and the Constitution, 1970 LAW \& SOC. ORDER 659, 660 n.6. "The English system of debtors' prisons was notoriously abusive." Note, Civil Arrest of Fraudulent Debtors: Toward Limiting the Capias Process, 26 RUTGERS L. Rev. 843, 854 (1973). "The most famous of debtor's prisons" was the Fleet prison. Abraham L. Freedman, Imprisonment for Debt, 2 TEMP. L. Q. 330,349 \& n.69 (1928). Debtors imprisoned there "were vilely treated, tortured and starved." Id. at 349 n. 69.

${ }^{34}$ At common law there were two types of civil actions: personal actions and real actions. A personal action was a civil "action brought for the recovery of some debt or for damages for some personal injury, in contradistinction to the old real actions, which related to real property only." BLACK's LAW DICTIONARY 892 (1891).

${ }^{35}$ This writ, which was then issued as a matter of course in most personal actions, "commands the sheriff to take the defendant, and him safely keep, so that he may have his body before the court on a certain day, to answer the plaintiff in the action." Black's Law Dictionary 168 (1891). In the seventeenth century, the writ was in Latin.

"At common law, the writ of capias ad respondendum was used as a means to take a debtor into custody until he furnished security for a creditor's claim. ... Thus, [the writ of capias ad respondendum], a body attachment, insured the defendant's presence before the court." Eugene J. Morris \& Hilton M. Wiener, Civil Arrest: A Medieval Anachronism, 43 Brook. L. REv. 383, 384 (1976) (footnote omitted). "Capias ad respondendum, the writ initiating the creditor's suit, is essentially a body attachment." Note, Civil Arrest of Fraudulent Debtors: Toward Limiting the Capias Process, 26 RUtgers L. REV. 843, 856 (1973). 
tered (and who could not pay it) were subject to imprisonment, sometimes for years, under a writ of capias ad satisfaciendum, ${ }^{36}$ which legalized a harsh regime of imprisonment for debt. ${ }^{37}$ In addition to these two capias writs, there were still other civil arrest warrants available to authorize the arrest of a party in a personal action. $^{38}$

This flourishing, oppressive civil arrest regime made it highly probable that on occasion members of the High Court of Parliament as well as their servants would be caught up in the toils of the system and inevitable that at least in some cases the arrest would violate parliamentary privilege. And whenever a member or a servant of a member of a House of Parliament, for whatever reason, found

${ }^{36}$ This writ, in Latin in the seventeenth century, was authorized as a matter of course in personal actions in which a writ of capias ad respondendum had previously issued. The writ of capias ad satisfaciendum "commands the sheriff the sheriff to take the party named, and keep him safely, so that he may have his body before the court on a certain day, to satisfy the party by whom it is issued, the damages or debt and damages recovered by the judgment. Its effect is to deprive the party of his liberty until he makes the satisfaction awarded." BLACK's LAW DICTIONARY 168 (1891).

The writ of capias ad satisfaciendum, "which became operative after judgment, provided for incarceration after trial, where the judgment remained unsatisfied. Thus, ... [capias as satisfaciendum], a writ of body execution, enforced payment of the judgment." Eugene J. Morris \& Hilton M. Wiener, Civil Arrest: A Medieval Anachronism, 43 BROOK. L. REv. 383, 384 (1976). Under the capias ad satisfaciendum "[t]he defendant is incarcerated until he ... pays the judgment ..." Note, Civil Arrest of Fraudulent Debtors: Toward Limiting the Capias Process, 26 RUTGERS L. REV. 843,856 (1973).

37 "The capias ad satisfaciendum, as its name implies, is a writ issued to imprison the body of the debtor until satisfaction be made of the debt, costs, and damages. By this writ a debtor could be thrown into prison at the mere will of the plaintiff until he satisfied the debt; and his poverty was no excuse. Yet no opportunity was afforded him to work; he was to be kept in close custody, and the sheriff could not for a moment permit him to go at large, else the officer was guilty of an escape, and the debt fell upon his own head, irrespective of the debtor's financial condition. The plaintiff himself could not consent to the debtor's release, for this constituted an absolute and irrevocable satisfaction of the judgment, irrespective of any understanding or agreement to the contrary, and an agreement that the defendant would in certain contingencies, redeliver himself to be held under execution could not be enforced, nor did it save the debt from discharge." Abraham L. Freedman, Imprisonment for Debt, 2 TEMP. L. Q. 330, 347-48 (1928) (footnotes omitted).

${ }^{38}$ See Richard Ford, Imprisonment for Debt, 25 MiCH. L. REv. 24, 27 (1927) (mentioning writs of testatum capias, of latitat, and of quo minus); Abraham L. Freedman, Imprisonment for Debt, 2 TEMP. L. Q. 330, 349 \& n.69 (1928) (same). 
himself under arrest in violation of the privilege, the writ of habeas corpus, available in that House, was an accepted-indeed, the usual-remedy for obtaining release from custody in the Jacobean period. Under these circumstances, habeas corpus in the High Court of Parliament was, for what must have been hundreds or more of persons protected by parliamentary privilege, a most useful tool for escaping the rigors of the civil arrest system. To the extent parliamentary privilege provided protections from this system, it was clearly a valuable right; and to the extent parliamentary habeas corpus furnished a remedy against violations of the privilege, it must have seemed a treasured remedy.

The civil arrest system, in short, made it practically certain that during the reign of James I persons imprisoned under civil arrest process who claimed the protection of parliamentary privilege would find themselves applying for the habeas corpus remedy, or perhaps some other remedy, in the High Court of Parliament.

D. NON-HABEAS PARLIAMENTARY REMEDIES FOR VIOLATIONS OF FREEDOM FROM ARREST

\section{Release by Writ of Privilege}

Although habeas corpus in the High Court of Parliament was, during the reign of James 1 , a commonly used remedy in cases where a violation of the parliamentary privilege from arrest had occurred, it was not the only parliamentary remedy available in such cases. The writ of privilege, for example, rather than the writ of habeas corpus, was occasionally used by a House of Parliament to release an imprisoned person whose confinement violated the parliamentary privilege. ${ }^{39}$

\section{Release without Writ}

In addition, a person imprisoned in contravention of the parliamentary privilege could be discharged from custody by order of a

${ }^{39}$ See, e.g., In re Eustache Parry, Sir James Scudamore's Man (H.C. 1609/10, 1610), in (1) 1 H.C.Jour. 406, 412, 414, 415-16, 435, and (2) 1 HATSEL 162 (by writ of privilege, servant of member of House of Commons ordered discharged from imprisonment under civil arrest process); In re William Trussell (H.L. 1604), in 2 H.L.Jour. 277, 278 (by writ of privilege, servant of member of House of Lords ordered discharged from imprisonment under civil arrest process). 
House of Parliament, without the issuance of any writ of habeas corpus or writ of privilege, ${ }^{40}$ and this sometimes happened. ${ }^{41}$

\section{Contempt Remedy}

There was still another remedy a House of Parliament would use from time to time to protect the parliamentary privilege from arrest. This was the contempt remedy, under which the House treated violations of the arrest privilege as contempt or breach of privilege. ${ }^{42}$ The purpose of the remedy was not to release anyone from

40 "Although the privilege of either House of Parliament was admitted to entitle a prisoner to his release, the manner of releasing him was, during the seventeenth century, still indefinite, whether by warrants for a writ of privilege or a writ of habeas corpus, or by the order of the House." Erskine May's Treatise on The LaW, Privileges, Proceedings and Usage of Parliament 95 (C.J. Boulton ed., 21st ed. 1989).

${ }^{41}$ See, e.g., In re Edward Teryngham (H.L. 1624), in 3 H.L.Jour. 385, 386 (without writ, servant of member of House of Lords ordered discharged from custody); In re James Bynd (H.L. 1614), in 2 H.L.Jour. 703, 704 (without writ, servant of Archbishop of Canterbury ordered discharged from custody).

According to James S. HaRt, Justice Upon Petition: The House of LoRds and the ReforMATION OF JUSTICE 1621-1675, at $60 \mathrm{n} .108$ (1991), the practice of releasing prisoners by writ of habeas corpus, rather than releasing them without writ, "was usually used."

There do not appear to be any cases in the reign of James I in which the House of Commons, without either a writ of habeas corpus or a writ of privilege, actually released someone imprisoned in violation of the parliamentary privilege. There can be no doubt that they had the power to do so, however. Less than a year after James I's death, that House, in response to a committee report recommending that an imprisoned member be released via a writ of habeas corpus, "declare[d], that ... the House hath Power, when they see Cause, to send the [sergeant at arms] immediately, to deliver a prisoner [without issuance of any writ]." 1 H.C.Jour. 820 (Feb. 15, 1625/6).

42 "Technically, the power of Parliament to punish for contempt traces back to the High Court of Parliament and thus is a judicial power." Jerry S. Williams, The Parliamentary Privilege Limitation on Freedom to Criticize the British House of Commons, 42 TEx. L. Rev. 1, 31 (1963).

Distinguishing contempt of Parliament from breach of parliamentary privilege is not always easy. Contempt of either House of Parliament includes "[a]ny act which either directly obstructs the due proceeding of that House or has a tendency to produce that effect by bringing its authority into contempt .... Such acts are usually described as breaches of privilege, but this is not strictly correct. All breaches of privilege are contempts of the House whose privileges are violated, but a person may be guilty of a contempt of one or the other House without violating any privilege properly so called of that House, e.g., by disobeying an order to attend in committee." L.A. Abraham \& S.C. Hawtrey, A Parliamentary Dictionary 
imprisonment but to punish offenders who had violated the privilege, and to deter future violations of the privilege.

\section{(a) House of Lords}

Standard procedures were followed in implementing the contempt remedy in the House of Lords in cases of violation of the parliamentary privilege against arrest. If informed that there had been a violation, the House usually would order the arrest of the persons allegedly responsible for the violation of privilege. ${ }^{43}$ Frequently the House would order the arrest at the very same time that it would order a writ of habeas corpus issued in regard to the person whose imprisonment allegedly violated the parliamentary privilege. ${ }^{44}$ Pursuant to the arrest order, the sergeant at arms of the House of Lords would take the alleged offenders named therein into custody and bring them as prisoners before the House. ${ }^{45}$ The persons brought before the House typically would include a civil plaintiff (almost always a creditor) who had procured the arrest, and an officer who had actually made the arrest. ${ }^{46}$ If a plaintiff or officer responsible for the arrest who was brought before the House had not known that the arrestee was privileged, or if he acknowledged his fault

80 ( $2 \mathrm{~d}$ ed. 1964). "The distinction between a contempt and a breach of privilege lies in the fact that the latter is an offence against a specifically established privilege of Parliament, whereas the former is an offence based on precedents which are less easily defined." An EnCrClopedia of ParlaAment 175 (Norman Wilding \& Philip Laundy eds., 4th ed. 1971).

${ }^{43}$ See, e.g., 3 H.L.Jour. 176 (Nov. 30, 1621) (House ordered sergeant at arms to bring before their lordships the two persons allegedly responsible for an arrest violative of parliamentary privilege, to answer for their contempt and breach of privilege); 2 H.L.Jour. 703 (May 16, 1614) (House ordered that sergeant at arms take and bring before their lordships the three persons responsible for an arrest that violated parliamentary privilege, to answer for their contempt).

${ }^{44}$ See, e.g., In re Sir Edward Osbaldeston (H.L. 1623/4), in 3 H.L.Jour. 261; in re Thomas Musgrove (H.L. 1607), in 2 H.L.Jour. 497.

${ }^{45}$ See. e.g., 2 H.L.Jour. 703, 704 (May 16, 19, 1614) (House ordered that sergeant at arms take and bring before their lordships the three persons responsible for arrest that violated parliamentary privilege, to answer for their contempt; thereafter, the three offenders were brought to the bar of the House by the sergeant at arms to answer for their offense and contempt).

${ }^{46}$ See, e.g., 2 H.L.Jour. 588 (May 5, 1610) (sergeant at arms ordered to bring to the House, to answer for their contempt and breach of privilege, the civil plaintiffs who procured arrest of servant of member of House, and the officers who made that arrest). 
and humbly apologized for the arrest, he probably would be set free ${ }^{47}$ If, however, the person responsible for the arrest had known the arrestee was privileged but thereafter in the House of Lords refused to admit guilt, declined to apologize, or failed to humbly submit himself to the House, he might be sent to prison. ${ }^{48}$ If the violation of the parliamentary arrest privilege had been flagrant or insolent, the offender could be sentenced not only to imprisonment but also to undergo degrading public humiliation. ${ }^{49}$

\section{(b) House of Commons}

During the Jacobean era the House of Commons, like the House of Lords, had power to punish contempt, ${ }^{50}$ and it would order the arrest and imprisonment for contempt of offenders who had procured or made an arrest that violated parliamentary privilege. ${ }^{51}$

${ }^{47}$ See, e.g., 3 H.L.JouR. 179 (Dec. 3, 1621) (person who procured arrest of servant of this House discharged from any contempt because he did not know arrestee was privileged); 3 H.L.JouR. 96 (Apr. 28, 1621) (officer who made arrest that violated parliamentary privilege confessed his fault and submitted himself, and was then released from custody); 3 H.L.Jour. 58 (Mar. 21, 1620/1) (officer who made arrest that violated parliamentary privilege confessed his offense, was brought to the bar where he made his submission, and thereupon was released from custody).

${ }^{48}$ See, e.g., 3 H.L.Jour. 386 (May 15, 1624) (civil plaintiff responsible for arrest that violated parliamentary privilege committed to Fleet prison until he makes his submission).

${ }^{49}$ See, e.g., 3 H.L.Jour. 31 (Feb. 27, 1620/1) (because sergeants-at-mace making arrest had willfully infringed parliamentary privilege from arrest, and because they had spoken of this high court with great contempt, they are sentenced to imprisonment and additionally to "be set on Horseback, at or near Westminster-Hall, neither of them to have or wear any Cloak or Hat; both of them to have, or bear fastened on their Breasts and Backs, several papers, wherein shall be expressed their fault, in hoc verba: For a Contemptuous Breach of the Privileges of Parlaament, Belonging to the Servants of the lords of Parliament, aggravated by Contemptuous SPEECHES. And in that sort the said Offenders ... are, with soft and easy pace, to pass through Holborne, until the further end of Cheapside; and then to return [to prison]...").

${ }^{50}$ The power of the English House of Commons to punish for contempt "goes back to the period when the bishops, the lords, and the knights and burgesses met in one body, and were, when so assembled, called the High Court of Parliament." Kilbourn v. Thompson, 103 U.S. 168, 183 (1880).

${ }^{51}$ At the time that it ordered issuance of the first writ of habeas corpus in the case of the imprisonment of Sir Thomas Shirley, the House of Commons ordered its own sergeant at arms to bring in the creditor who had procured Shirley's arrest and an officer who made the arrest, 1 H.C.Jour. 149 (Mar. 22, 1603/4), and five 


\section{E. PARLIAMENTARY HABEAS REMEDY FOR VIOLATIONS OF FREEDOM FROM ARREST}

During the reign of James $I$, a habeas corpus proceeding in either the House of Lords or the House of Commons of the High Court of Parliament was a principal remedy for obtaining release from imprisonment which violated the parliamentary privilege from arrest.

In that reign, habeas corpus proceedings in the High Court of Parliament were similar, in terms of practice and procedure, to traditional habeas proceedings in the common law courts of England. In habeas proceedings in the High Court of Parliament, as in habeas proceedings in the Courts of King's Bench or Common Pleas, claims of unlawful imprisonment were presented to a judicial tribunal; writs of habeas corpus were issued; returns were made; prisoners were produced; discharges from custody were ordered. These habeas proceedings in the High Court of Parliament were classic examples of a habeas corpus proceeding in a court of judicature. Unquestionably, the High Court of Parliament was then a judicial tribunal with habeas corpus jurisdiction.

During James I's reign, there were a total of forty-two habeas corpus proceedings in the High Court of Parliament-thirty-five in the House of Lords and seven in the House of Commons. In all but three of the forty-two cases the prisoner appears to have been in custody under civil arrest process. In not a single one of the habeas cases in the High Court of Parliament in the reign of James $I$ is there any indication that relief was sought or granted on any ground other than violation of parliamentary privilege. In all but seven of the cases, the prisoner seeking habeas relief was or claimed to be a servant of a member of one of the Houses of Parliament.

days later these two offenders were brought into the House by the sergeant at arms, 1 H.C.JOUR. 155 (Mar. 27, 1603/4). After the two men apparently had been released from custody temporarily, the House again ordered the sergeant at arms to bring the two men in. 1 H.C.JouR. 167-68 (Apr. 11, 1604). Two days later the House committed the two to prison. 1 H.C.Jour. 171 (Apr. 13, 1604)

On another occasion the House of Commons ordered its sergeant at arms to bring in a justice of the peace who, allegedly in violation of the parliamentary arrest privilege, had committed a servant of a member of the House to prison. The justice remained in the custody of the sergeant at arms for a day or two. Then, after the House resolved that he should be punished, the justice acknowledged his fault and was released from custody. See 1 H.C.Jour. 270, 272-73 (Feb. 18, 19, 22, 1605/6); see also 1 HATSEL 132 (stating that the justice of the peace was committed to the custody of the sergeant of arms and that "on his submission and acknowledging his fault," the justice was discharged). 
Habeas relief was granted in at least thirty-two $(77 \%)$ of the fortytwo cases.

\section{HABEAS PROCEEDINGS IN THE HOUSE OF LORDS, 1603-1625}

\section{A. OVERVIEW}

During the reign of James I there were thirty-five separate habeas corpus proceedings in the House of Lords of the High Court of Parliament. ${ }^{52}$ Six of these habeas cases were in 1604; four in 1607; two in 1610; four in 1614; three in 1620/1; twelve in 1621; two in $1623 / 4$; and two in $1624 .^{53}$

In all thirty-five habeas cases in the House of Lords civil arrest process was the cause of the imprisonment under attack. ${ }^{54}$

In none of the thirty-five cases was the imprisoned person seeking habeas relief a member of the House of Lords, i.e., a lord spiritual or temporal. In most cases the prisoner was a servant. In twenty-six of the cases the imprisoned person was or claimed to be a servant of a lord temporal; in two cases the imprisoned person was a servant of a lord spiritual; and in four cases the imprisoned

52 These thirty-five cases, with full citations, are listed in chronological order infra in Part A of Appendix 1, which also provides certain background information on the cases. Whenever one of these cases is cited in a footnote, only the applicable portion of the citation is given unless the full citation is appropriate.

${ }^{53}$ See infra Part A of Appendix 1.

During the reign of James $I$, there were only four Parliaments. The first had five sessions and sat from March to July 1604; from November 1605 to May 1606; from November 1606 to July 1607; from February to July 1610; and from October to December 1610. The second, the famous Addled Parliament (examined in THE CRISIS of 1614 and the Added Parliament (Stephen Clucas and Rosalind Davies eds., 2003), and Thomas L. Molr, The Addled Parliament of 1614 (1958)), sat from April to June 1614. The third (examined in Robert Zaller, The PARLIAMEnt of 1621: A Study in ConSTITUTIONAL CONFLICT (1971)) sat from January to December 1621. The final Parliament of the reign sat from February to May 1624. Thus, in a reign of twenty-two years, Parliament met in only eight calendar years, and sat for a total of only fifty months. For the precise dates of the meetings of James I's Parliaments, see DaVID L. SMITH, The StUART Parliaments 1603-1689, at 236 (1999).

${ }^{54}$ There is nothing in the Journal of the House of Lords or in the Parliamentary Archives to suggest that any of the habeas cases in that House during the Jacobean period involved imprisonment not under civil process. Every legible return in the Parliamentary Archives from the Jacobean period indicates that the habeas petitioner was imprisoned under civil arrest process. 
person was a royal servant. ${ }^{55}$ In three cases ${ }^{56}$ the imprisoned person was a nonservant who, under the circumstances, was entitled to parliamentary privilege. ${ }^{57}$

On the whole, imprisoned persons were quite successful in their efforts to obtain habeas relief from the House of Lords. In not less than twenty-eight ( $80 \%)$ of the thirty-five cases the prisoner was ordered discharged from custody. ${ }^{58}$

\section{B. PRACTICE AND PROCEDURE}

\section{Commencement of Proceeding}

In eleven of the thirty-five habeas cases in the House of Lords the proceeding commenced with the presentation of a written petition in behalf of the imprisoned person complaining that imprisonment was unlawful. In twenty-two of the cases the proceeding commenced, not with a written petition, but with the House of Lords being verbally informed of the alleged unlawful imprisonment by a named or unnamed member of the House. In one case ${ }^{59}$ the habeas proceeding was commenced based upon a verbal report made to the House by a lawyer employed as legal counsel and messenger

${ }^{55}$ See infra Part A of Appendix 1.

For purposes of the parliamentary privilege from arrest, royal servants were then considered to stand on the same footing as servants of members of the House of Lords. It was not until 1693 that the House of Lords ceased entertaining habeas petitions filed by royal servants; see 15 H.L.Jour. 205 (Nov. 23, 1693) ("this Day Ordered, ... . That this House will not receive any Petition for protecting Their Majesties [sic] Servants...").

${ }^{56}$ See infra Part A of Appendix 1.

57 In both In re Richard Dyke (H.L. 1621), in 3 H.L.Jour. 165, 170, and In re Francis Broade (H.L. 1621), in (1) 3 H.L.Jour. 94, 96, and (2) HMC 3d 22, the habeas claim was that, in violation of parliamentary privilege, the imprisoned person had been subjected to a civil arrest while under orders from the House of Lords to attend from day to day in connection with a matter pending there. In the third case, In re Benjamin Crokey (H.L. 1621), in 3 H.L.JouR. 170-71, 173-74, the imprisoned person claimed that parliamentary privilege had been violated when he was fraudulently arrested on trumped-up debt accusations to prevent him from executing a commission from the House of Lords to settle the possessions of a suppressed collegiate free school. Finding that parliamentary privilege had been violated, the House of Lords granted habeas relief in all three cases.

${ }^{58}$ See infra Part A of Appendix 1. Relief was denied in two cases, while in five cases it is unclear whether relief was granted or denied. Id.

${ }^{59}$ See infra note 75 and accompanying text. 
for the House. In one case ${ }^{60}$ it is not known how the habeas proceeding was brought before the House of Lords.

\section{(a) Habeas Petitions}

Of the eleven habeas cases commenced by written petition, eight involved a petition to the House of Lords by the imprisoned person himself, ${ }^{61}$ and one involved a petition to the House of Lords presented by a third party in behalf of the imprisoned person..$^{62}$ The other two cases appear to have begun with the presentation of a petition by the imprisoned person to an individual member of the House of Lords..$^{63}$ A petition was presented to the House of Lords by being delivered to the Clerk of the Parliaments. ${ }^{64}$ The petition

${ }^{60}$ In re Richard Taylor (H.L. 1614), in 2 H.L.Jour. 712. Taylor, a servant of a temporal peer, was brought before the House of Lords pursuant a writ of habeas corpus ordered by the House, and thereafter discharged from custody, but there is no indication how the fact of his imprisonment was brought to the attention of the House.

${ }^{61}$ See In re George Hume (H.L. 1621), in 3 H.L.Jour. 198; In re Abraham Watts (H.L. 1621), in 3 H.L.JOUR. 192; In re William Whorewood (H.L. 1621), in 3 H.L.JouR. 176; In re Benjamin Crokey (H.L. 1621), in 3 H.L.Jour. 170; In re William Cowse (H.L. 1621), in 3 H.L.Jour. 169; In re Francis Broade (H.L. 1621), in 3 H.L.Jour. 94; In re Sir Henry Fynes (H.L. 1621), in 3 H.L.Jour. 88; In re Solomon Browne (H.L. 1620/1), in 3 H.L.Jour. 27.

${ }^{62}$ See In re Richard Dyke (H.L. 1621), in 3 H.L.Jour. 165 (two individuals who were bail for personal appearance of Dyke in House of Lords in matter pending in House of Lords petitioned that Dyke, who had now been civilly arrested, be sent for so that order could be entered consistent with honor and privileges of House of Lords).

The habeas petition in Dyke is what is called a next friend petition.

${ }^{63}$ See In re Sir Edward Osbaldeston (H.L. 1623/4), in HMC3d 29 (petition to Earl of Pembroke, Lord Chamberlain, complaining of civil arrest and asking for privilege of Earl of Derby, whose servant petitioner is); In re John Nanton (H.L. 1621), in HMC 3d 22 (petition to Thomas, Lord Cromwell to take steps for enlargement from civil arrest of petitioner, who is one of his servants). In Osbaldeston, the House of Lords may have treated the petition as a petition to the House itself, see 3 H.L.Jour. 261 , and in Nanton the petition apparently resulted in the issue of the imprisonment being presented to the House by an unnamed member who was not Lord Cromwell.

64 James S. Hart, Justice Upon Petition: The house of Lordos and the Reformation of JUSTICE 1621-1675, at 36 (1991).

The Clerk of the Parliaments is "[t]he chief permanent officer of the House of Lords. He is appointed by the Crown by letters patent... . The office of Clerk of the Parliaments appears to date from the early Parliaments of the reign of Edward I. . . [ [1]n 1510 the actual style 'Clerk of the Parliaments' makes its first appear- 
would then be read out loud to the House, ${ }^{65}$ presumably by the Clerk of the Parliaments.

Petitions presented to the House of Lords had to be handwritten in English on parchment, and there were strict rules prescribing the form of such petitions. ${ }^{66}$ First, the petition had to begin with a superscription respectfully announcing that the petition was addressed to the House of Lords. A frequent superscription was "To the Right Honourable the Lords Spiritual and Temporal in the High Court of Parliament Assembled" or words to the like effect. Next, the petition had to designate who the petitioner was. The standard designation of petitioner was "The Humble Petition of [name of petitioner]." Third, the factual allegations of the petition had to be set forth, almost always preceded by "Sheweth" or "Shewing".

ance." AN EnCrClopedia of Parliament 136-37 (Norman Wilding \& Philip Laundy eds., 4th ed. 1971). See also Maurice F. Bond, The Office of Clerk of the Parliaments, 12 Parlamentary Affalrs 297 (1959) (describing duties of Clerk of the Parliaments).

In the reign of James I the Clerk of the Parliaments "wore a barrister's black gown. He attended the House [of Lords] each day and took the notes which he later revised for a finished journal." Elizabeth Read Foster, Procedure in the House of Lords During the Early Stuart Period, 5 J. BRIT. STUD. 56, 64 (1966) (footnotes omitted). On a woolsack facing the throne in the chamber of the House of Lords, he sat next to the Clerk of the Crown in Chancery, who would act in his place if he were absent. Elizabeth Read Foster, The Painful Labour of Mr. Elsyng, 92 TransACtions of the American Philosophical Society (n.s. pt. 8) 11 (Dec. 1972).

During the reign there were three Clerks of the Parliaments. The first was Sir Thomas Smith, who was in office when James I acceded to the crown and who kept that office until he died in November 1609. The second was Robert Bowyer, who succeeded to the office on Smith's death and remained in office until resigning in March 1620/1. The third was Henry Elsynge, who succeeded to the office a few days after Bowyer's resignation and was still in office at the time of James l's death. See Maurice F. Bond, Clerks of the Parliaments, 1509-1953, 73 ENG. HIST. REv. 78, 83 (1958).

${ }^{65}$ See, e.g., In re Richard Dyke (H.L. 1621), in 3 H.L.Jour. 165 ("The humble Petition of William Garrowaye and Anthony Gibson [in behalf of Dyke] was read ...."); In re Sir Henry Fynes (H.L. 1621), in 3 H.L.Jour. 88 ("The Petition of Sir Henry Fynes, a Gentleman of the King's Privy Chamber, was read ....").

${ }^{66}$ Many of these rules remain in effect today, although petitions may now be written, printed or typed on paper. See Rules 3.75 through 3.76, COMPANION TO THE Standing Orders and Guide to the Proceedings of the House of Lords (2010), www.publications.parliament.uk/pa/ld/ldcomp/compso2010/ldctso02.htm. See also An ENCrClopedia OF PARLIAMENT 563-64 (Norman Wilding \& Philip Laundy eds., 4th ed. 1971) (discussing formal requirements of petitions submitted to a House of Parliament); L.A. Abraham \& S.C. Hawtrey, A Parliamentary Dictionary 145-48 (2d ed. 1964) (same); Erskine May's Treatise on The Law, Privileges, Proceedings and Usage of Parliament 75455 (C.J. Boulton ed., 21st ed. 1989) (same). 
Fourth, there had to be a prayer for relief, specifying what the petitioner wanted done. Fifth, there would be a conclusion, which would usually consist of the formulaic phrase "And your petitioner shall ever pray, etc." or words to the same effect, and would be followed by the signature of the petitioner.

Of the nine habeas petitions presented to the House of Lords during the reign of James I, only one exists in full text. This is the 1621 petition of William Cowse. It is printed verbatim in the Journal of the House of Lords, while the original parchment petition itself is in the Parliamentary Archives. This petition, which complies meticulously with the requirements governing the form of petitions to the House of Lords, is set out in the margin. ${ }^{67}$ Another petition is available only in a paraphrased version, ${ }^{68}$ and there is limited infor-

${ }^{67}$ To the Right Honourable the Lords Spiritual and Temporal in His Majesty's High Court of Parliament assembled.

The Humble Petition of William Cowse, now Prisoner in Ludgate, and Servant to the Right Honourable the Lord Stafford.

Shewing,

That whereas, your Petitioner being his Lordship's Servant, it pleased his Lordship to grant unto your Petitioner his Protection; and yet, notwithstanding, your Petitioner (by James Moorton and Robert Campion, Officers to the Sheriffs of London), upon the 30th of June last, was arrested in Execution, at the Suit of one Mr. Goade and William Jennyngs, and hath been ever since detained in Prison, and several Suits by other Men prosecuted against him; all his Goods being seized, and, by Reason thereof, your Petitioner was not able to pay his Rent, and so forfeited the Lease of his House at Michaelmas last, being worth Three Hundred Pounds to be sold, and your Petitioner quite cast out of his House.

May it therefore please your Honours to take the same into your Honourable Consideration, and to free your Petitioner, according to the Privilege of your House and Honourable Court of Parliament, as also according to an Act of Parliament made in Primo of His Majesty. And that your Honours would be likewise please to question the said Goad [sic] for his contemptuous Words; saying, He neither regarded the Protection, nor your Lordships Orders, nor any Things else your Lordships could do, no more than he regarded a Rush.

And your Petitioner, his Wife and Children, shall daily pray for your Honours Happiness.

\section{[Signature of William Cowse]}

In re William Cowse (H.L. 1621), in 3 H.L.JouR. 169. The original petition, on a piece of parchment fifteen and one-half inches high by twelve and one-half inches wide, is referenced $\mathrm{HL} / \mathrm{PO} / \mathrm{JO} / 10 / 14 / 4 / 3362$ in the Parliamentary Archives.

It is worthy of note that Cowse's petition distinctly invokes the Privilege of Parliament Act, 1603 ("an Act of Parliament made in Primo of His Majesty").

${ }^{68}$ See In re Benjamin Crokey (H.L. 1621), in 3 H.L.Jour. 170, 170-71, in which the contents of the petition are paraphrased in four paragraphs consisting of over 300 words. The original parchment petition is not in the Parliamentary Archives. 
mation on the exact contents of the remaining seven petitions. ${ }^{69}$ But doubtless the petitions all had the same gist. Each of the nine petitions appears to have complained, directly or indirectly, of imprisonment alleged to violate parliamentary privilege.

The prayer for relief in a habeas petition submitted to the House of Lords did not always contain an express request a writ of habeas corpus. One of the petitions desired the House "to send for the body of the [imprisoned person] that thereupon such Order may be taken, as shall stand with the Honour and Privileges of this Honourable Court."70 Another requested the House "to free your Petitioner, according to the Privilege of your House and Honourable Court of Parliament". ${ }^{71}$ Still another requested that the petitioner "be discharged". ${ }^{72}$ Only one of the petitions is known for certain to have explicitly requested a writ of habeas corpus in the prayer for relief. ${ }^{73}$ Nonetheless, it cannot be seriously doubted that the nine petitions, each of which resulted in issuance of a writ of habeas corpus, were habeas petitions. A petition to a court in behalf of an imprisoned person complaining that the imprisonment is unlawful, which results in the issuance of a writ of habeas corpus (or an order for the issuance of the writ) by the court, for the purpose of inquiry into the lawfulness of the imprisonment, is a habeas petition, irrespective of whether the petition expressly requests a writ of habeas corpus. The nine petitions unquestionably were habeas petitions.

\section{(b) Proceedings Without Petition}

Of the twenty-three habeas cases known to have been commenced other than by the submission of a habeas petition, ${ }^{74}$ all but

${ }^{69}$ See In re George Hume (H.L. 1621), in 3 H.L.Jour. 198; In re Abraham Watts (H.L. 1621), in 3 H.L.Jour. 192; In re William Whorewood (H.L. 1621), in 3 H.L.Jour. 176; In re Richard Dyke (H.L. 1621), in 3 H.L.Jour. 165; In re Francis Broade (H.L. 1621), in 3 H.M.C. 3d 22; In re Sir Henry Fynes (H.L. 1621), in (1) 3 H.L.Jour. 88, and (2) HMC 3d 22; In re Solomon Browne (H.L. 1620/1), in HMC 3d 18. In each of these cases the original petitions themselves are not in the Parliamentary Archives. What is known of them consists of summary descriptions of their contents, usually quite brief, in the Journal of the House of Lords or a Report of the Royal Historical Manuscripts Commission.

${ }^{70}$ See In re Richard Dyke (H.L. 1621), in 3 H.L.Jour. 165.

${ }^{71}$ See In re William Cowse (H.L. 1621), in 3 H.L.Jour. 169.

72 See In re Henry Fynes (H.L. 1621), in HMC 3d 22.

${ }^{73}$ See In re Solomon Browne (H.L. 1620/1), in HMC3d 18 ("Petition of Salomon [sic] Browne ... prays for a writ of Habeas Corpus."). 
one ${ }^{75}$ began when the House of Lords was notified of the alleged unlawful imprisonment in a verbal statement to the House made by one of its members. ${ }^{76}$ In five of these twenty-two cases the member giving the notification was the lord spiritual or temporal whom the imprisoned person claimed to be serving, ${ }^{77}$ and in nine cases the imprisonment was brought to the attention of the House by some other named member of the House. ${ }^{78}$ In eight cases the House of

${ }^{74}$ See In re Richard Culpeper (H.L. 1624), in 3 H.L.Jour. 415; in re Welsbourne Sill (H.L. 1624), in 3 H.L.JouR. 385; In re John Phillipps (H.L. 1623/4), in 3 H.L.JouR. 247; In re Henry Lucye (H.L. 1621), in 3 H.L.Jour. 182; In re Originall Bellamye (H.L. 1621), in 3 H.L.JOUR. 136; In re John Nonne (H.L. 1621), in 3 H.L.JouR. 119; In re William Jewell (H.L. 1620/1), in 3 H.L.Jour. 45; In re John Robinson (H.L. 1620/1), in 3 H.L.JouR. 25; In re Sir David Wood (H.L. 1614), in 2 H.L.JouR. 710; In re George Belgrave (H.L. 1614), in 2 H.L.Jour. 694; In re Roger Bradshaw (H.L. 1614), in 2 H.L.JouR. 691; In re William Lodar (H.L. 1610), in 2 H.L.Jour. 597; In re William Heylocke (H.L. 1610), in 2 H.L.Jour. 588; in re John Danson (H.L. 1607), in 2 H.L.JouR. 513; In re John Foster (H.L. 1607), in 2 H.L.Jour. 511; In re Nathaniell Butler (H.L. 1607), in 2 H.L.Jour. 509; In re Thomas Musgrove (H.L. 1607), in 2 H.L.Jour. 497; in re Marmaduke Redmaine (H.L. 1604), in 2 H.L.Jour. 315; In re Nicholas Reading (H.L. 1604), in 2 H.L.JouR. 308; in re Robert Quinell (H.L. 1604), in 2 H.L.Jour. 299; In re John Piggott (H.L. 1604), in 2 H.L.Jour. 296; In re William Allome (H.L. 1604), in 2 H.L.JOuR 285; in re Thomas Rush (H.L. 1604), in 2 H.L.Jour. 270.

75 This case was in re William Jewell (H.L. 1620/1), in 3 H.L.Jour. 45, which commenced based on a verbal report made to the House by a barrister who was legal counsel to the House.

${ }^{76}$ Commencing a habeas case by verbal statement rather than by written petition seems strange today, but it was an accepted practice in seventeenth century England. In the Court of King's Bench, for example, habeas corpus writs could be issued based on an oral motion of counsel. See PaUL D. HalLiday, Habeas Corpus: From ENGLAND TO EMPIRE 46 (2010) ("In most cases, especially before the seventeenth century, the court was moved to act by an oral motion in court, by which a barrister recounted details of a person's imprisonment. Individual judges, too, might hear such stories and grant the writ ....").

7 See in re John Phillipps (H.L. 1623/4), in 3 H.L.Jour. 247; In re John Nonne (H.L. 1621), in 3 H.L.Jour. 119; In re William Allome (H.L. 1604), in 2 H.L.Jour. 285; In re Nicholas Reading (H.L. 1604), in 2 H.L.JouR. 308; In re Robert Quinell (H.L. 1604), in 2 H.L.Jour. 299.

Phillipps and Reading were royal servants, and in both cases the matter of their imprisonment was presented to the House by the Lord Chamberlain in behalf of the king.

${ }^{78}$ See in re John Robinson (H.L. 1620/1), in 3 H.L.Jour. 25; In re George Belgrave (H.L. 1614), in 2 H.L.Jour. 694; In re William Lodar (H.L. 1610), in 2 H.L.JouR. 597; In re John Danson (H.L. 1607), in 2 H.L.Jour. 513; In re John Foster (H.L. 1607), in 2 H.L.Jour. 511; In re Nathaniell Butler (H.L. 1607), in 2 H.L.Jour. 509; In re Thomas Musgrove (H.L. 1607), in 2 H.L.JouR. 497; In re Marmaduke Redmaine (H.L. 1604), in 2 H.L.Jour. 315; In re Thomas Rush (H.L. 1604), in 2 H.L.Jour. 270. 
Lords was notified of the imprisonment by an unnamed member of the House. ${ }^{79}$

\section{Issuance of Writ}

Once the matter of the alleged unlawful imprisonment had been properly presented to the House of Lords by petition or other procedure, the House would authorize issuance of a writ of habeas corpus by approving an order directing that the writ be issued, frequently making it plain as it did so that it was acting as a court of judicature. ${ }^{80}$ The order would give the name of the particular imprisoned person who would have to be produced before the House pursuant to the habeas writ. If the case had originated with a petition to the House, the order of the House authorizing issuance of the writ would be inserted in handwriting at the foot of the petition. ${ }^{81}$

Having by order approved issuance of a writ of habeas corpus, the House of Lords would delegate the responsibility for actually issuing the writ to the Clerk of the Crown Office in Chancery. The Clerk of the Parliaments would therefore sign a warrant, addressed to the Clerk of the Crown in Chancery, that commanded issuance of a writ of habeas corpus for the production of the named prisoner. ${ }^{82}$ The warrant would be delivered to the Crown Office in

${ }^{79}$ See In re Richard Culpeper (H.L. 1624), in 3 H.L.Jour. 415; In re Welsbourne Sill (H.L. 1624), in 3 H.L.Jour. 385; In re Henry Lucye (H.L. 1621), in 3 H.L.Jour. 182; In re Originall Bellamye (H.L. 1621), in 3 H.L.JouR. 136; in re Sir David Wood (H.L. 1614), in 2 H.L.JOUR. 710; In re Roger Bradshaw (H.L. 1614), in 2 H.L.Jour. 691; In re William Heylocke (H.L. 1610), in 2 H.L.Jour. 588; In re John Piggott (H.L. 1604), in 2 H.L.JOUR. 296.

${ }^{80}$ See, e.g., In re John Robinson (H.L. 1620/1), in 3 H.L.Jour. 30 ("Upon Signification given to the House ... that one John Robinson, Servant in ordinary to the Earl of Oxford, Lord Great Chamberlain of England, hath been lately arrested, and committed to Prison ... contrary to the Honour and Privilege of this High Court; it is this day Ordered by the said Court, That a Writ of Corpus cum causa shall be awarded"); In re Solomon Browne (H.L. 1620/1), in 3 H.L.Jour. 27 ("Ordered, by the said Court, that the King's Majesty's Writ of Corpus cum causa be awarded").

${ }^{81}$ For example, the November 24, 1621 order of the House of Lords authorizing issuance of a writ of habeas corpus in the case of In re William Cowse (H.L. 1621), in 3 H.L.Jour. 169, is-presumably by the Clerk of the Parliaments-inserted in handwriting at the foot of the original parchment petition, which is referenced $\mathrm{HL} / \mathrm{PO} / \mathrm{JO} / 10 / 14 / 4 / 3362$ in the Parliamentary Archives.

At the time Henry Elsynge was Clerk of the Parliaments; see supra note 64.

82 See, e.g., In re Richard Dyke (H.L. 1621), in 3 H.L.JouR. 165 ("A Warrant [for writ of habeas corpus] delivered to the Deputy Clerk of the Crown [in Chancery] 
Chancery, where the habeas writ would promptly be drawn up and issued..$^{83}$ The writ of habeas corpus would be in Latin.

In the thirty-five habeas proceedings in the House of Lords during James I's reign, four writs of habeas corpus were issued in one case ${ }^{84}$ and two writs apiece were issued in two other cases, ${ }^{85}$ while in each

accordingly. Signed by the Clerk [of the Parliaments]."); In re John Nanton (H.L. 1621), in 3 H.L.Jour. 97 ("The Clerk [of the Parliaments] signed the Warrant to the Clerk of the Crown [in Chancery], for the making of the said Writ [of habeas corpus]"); In re Sir Henry Fynes (H.L. 1621), in 3 H.L. JouR. 89 ("A Warrant to the Clerk of the Crown [in Chancery], for the Habeas corpus cum causa ... [was] made accordingly, and signed by the Clerk [of the Parliaments].").

"The Clerk of the Crown in Chancery is appointed by Her Majesty under the Royal Sign Manual. He and his deputy are officers of both the House of Lords and of the House of Commons." Erskine May's Treatise on the Law, Privileges, Proceedings AND USAGE OF PARLIAMENT 191 (C.J. Boulton ed., 21st ed. 1989) (footnotes omitted). The Crown Office in Chancery "has custody of the Great Seal of the Realm ....." Clerk of the Crown in Chancery, http://en.wikipedia.org/wiki/Clerk_of_the_ Crown_in_ChanceryClerk of the Crown in Chancery. "The Lord Chancellor is head of the Crown Office, and the Clerk of the Crown the head of the permanent staff. ... It is in the Crown Office that the Great Seal . . . is affixed." AN ENCYCLOPEDIA OF ParlaAment 133-34 (Norman Wilding \& Philip Laundy eds., 4th ed. 1971). In the seventeenth century the Clerk of the Crown in Chancery sat next to the Clerk of the Parliaments on a woolsack below the king's throne in the chamber of the House of Lords, Elizabeth Read Foster, The House of Lords 1603-1649: Structure, Procedure, and the NATURE Of ItS Business 8, 44 (1983), and "Was always present" when the House of Lords was sitting, James S. HART, Justice Upon PETITION: THE HOUSE OF LORDS AND the Reformation of Justice 1621-1675, at 38 (1991).

During the reign of James I there were two Clerks of the Crown in Chancery. The first, Sir George Coppin, whose last name was sometimes spelled "Coppyn," was in office when James I acceded. He remained in office until 1620. The second, Sir Thomas Edmondes, took office in 1620 and was still Clerk when James I died. See J.C. Sainty, Clerk of the Crown in Chancery-List of Appointments, http://www. history.ac.uk/resources/office/chancery-appt.

${ }^{83}$ Since forty habeas writs were issued, there must have been forty of these warrants. None of the original warrants is in the Parliamentary Archives; nor is any of the warrants printed in the Journal of the House of Lords. Almost certainly, however, these warrants would have been in English and substantially similar to the warrants then used in the House of Commons to command the Clerk of the Crown in Chancery to issue the habeas writs ordered by that House.

${ }^{84}$ See In re Marmaduke Redmaine (H.L. 1604), in 2 H.L.Jour. 315, 316-17, 327 (first writ of habeas writ authorized by House on June 7; because after being brought before Lords on first writ Redmaine was left prisoner in custody of sheriff, second habeas writ authorized on June 9; because Redmaine was left in custody after second writ was returned, third habeas writ authorized on June 23; because Redmaine remained in custody, fourth habeas writ authorized on July 2).

${ }^{85}$ See In re John Nanton (H.L. 1621), in 11 MHL 147 (first habeas writ authorized by House on Apr. 28; because first writ had not been executed, second habeas 
of the remaining thirty-two cases one writ was issued. Thus, in thirty-five separate habeas corpus proceedings, a total of forty writs of habeas corpus were issued by order of the House of Lords for the purpose of inquiring into allegedly unlawful imprisonment.

None of the original habeas corpus writs issued by order of the House of Lords prior to 1620 has survived. Beginning in 1620/1, eighteen original writs of habeas corpus issued by order of the House of Lords in seventeen habeas proceedings during the final five years of the reign of James I are in the Parliamentary Archives. ${ }^{86}$ These writs are on separate parchment strips which range in size from one and one-half to two and three-quarter inches high and from nine to thirteen and one-half inches wide. ${ }^{87}$ They are signed by the Clerk of the Crown in Chancery. ${ }^{88}$ The writs run in the name of the king. They are addressed either to a sheriff or to a prison warden, jailer, or other custodian. Returnable to the House of Lords itself, they command that at a specified time the custodian produce the named imprisoned person, together with an explanation of the cause of his imprisonment.

The text of a typical example of one of the eighteen House of Lords habeas writs preserved in the Parliamentary Archives is set out in the margin. ${ }^{89}$

writ authorized on May 12); In re Solomon Browne (H.L. 1620/1), in 11 MHL 134 (first habeas writ authorized by House on Feb. 23, and because hearing on first writ put off, second habeas writ authorized on Feb. 24).

${ }^{86}$ These writs are listed infra in Appendix 2.

There are eighteen writs in seventeen cases because of the two writs in the case of in re Solomon Brown (H.L. 1620/1), in 11 MHL 134.

Sixteen of the eighteen writs are now partially illegible.

${ }^{87}$ See infra Appendix 2, which, in addition to listing the eighteen writs, gives the physical dimensions of the parchment strips on which these writs are written, as well as the Parliamentary Archives referencing designations of the writs.

${ }^{88}$ Eleven of the parchment writs of habeas corpus issued pursuant a warrant of the Clerk of the Parliaments in the reign of James I and now in the Parliamentary Archives are recognizably signed "Edmondes" or "Edmonds". This includes the writ issued in the case of in re Richard Culpeper (H.L. 1624), in (1) 3 H.L.JouR. 415, and (2) 11 MHL 163; see infra note 89. Sir Thomas Edmondes was the Clerk of the Crown in Chancery during the last five years of the reign of James I; see supra note 82.

${ }^{89}$ This is the writ issued on May 28, 1624 in the case of In re Richard Culpeper (H.L. 1624), in (1) 3 H.L.JouR. 415, and (2) 11 MHL 163. It provides:

Jacobus, Dei gratia, Angliae, Scotiae, Franciae, et Hiberniae Rex, fidei Defensor, etc. Salutem. Marescalus Marescalie nostro coram nobis. Praecipimus tibi, quod 


\section{Return to Writ}

The writ of habeas corpus was returnable "coram nobis magnatibus et proceribus in supiori domo parliament" [before us, the magnates and nobles in the upper house of parliament] - that is, to the House of Lords itself. Having been served with the writ of habeas corpus, the custodian to whom the writ was directed was required by the writ to do two things. First, he had to bring the imprisoned person into the chamber of the House of Lords at the time specified in the writ. Second, when he produced his prisoner before the Lords the custodian had to make a return to the habeas writ. The return, which would be in writing, would state the cause of the imprisonment and signify that the prisoner had been produced before the

habeas coram nobis magnatibus et proceribus in supiori domo parliamenti apud Westmonasterium corpus Richard Culpeper captionis et in prisona nostra, sub custodia tua, ut dicitur, detentionis, quocunque nomine, aut cognomine, idem Richard censeatur, una cum causa captionis et detentionis, ad respondendum super hiis, quae sibi tunc ibidem objicientur, et ad faciendum ulterius, et recipiendum, quod per nos, magnatibus et proceribus in parliamento nobis praedicto assemblat, consideratum et ordinatum fuerit: Et hoc nullatenus omittas, sicut Nobis inde respondere volueris. Et habeas ibid hoc breve. Teste Meipso, apud Westmonasterium, anno regni nostri, Angliae, Franciae, et Hiberniae, vicesimo secundo, et Scotiae, quinquagerimo septimo.

\section{Edmondes.}

[James, By the Grace of God, King of England, Scotland, France, and Ireland, Defender of the Faith, etc. To the Marshal of our Marshalsea before us. Greeting. We command you that you have before us, the magnates and nobles in the upper house of Parliament at Westminster, immediately after receiving this writ, the body of Richard Culpeper, detained in our prison under your custody, as it is said, by whatsoever name Richard may be called or known, together with the cause for the arrest and detention of the said Richard, and in addition there must be a response to that which then and there will be objected, and further to undergo and receive whatever we, the magnates and nobles in our aforesaid Parliament assembled, shall have considered and ordered: And this by no means omit, as thenceforth you will have wished you answered to us. And have there this writ. Witness myself at Westminster, the twenty-eighth day of May, in the twenty-second year of our reign in England, France, and Ireland, and in Scotland, the fiftyseventh.]

The original writ, on a parchment strip two and one-half inches high by twelve inches wide, is referenced $\mathrm{HL} / \mathrm{PO} / \mathrm{JO} / 10 / 14 / 4 / 3385$ in the Parliamentary Archives. For a reduced facsimile photograph of the writ, see infra Appendix 3 . Sir Thomas Edmondes, who signed the writ, was the Clerk of the Crown in Chancery in 1624; see supra note 82 . The text of the writ does not appear in the Journal of the House of Lords. 
House of Lords in accordance with the mandate of the writ. Returns were in Latin, and signed by the custodian.

Since thirty-nine of the forty writs of habeas corpus actually issued by order of the House of Lords in the reign of James I appear to have been properly served, it is highly probable that thirty-nine returns were made. ${ }^{90}$ However, there is solid evidence for the existence of only twenty-two returns, made in twenty-one of the thirtyfive habeas cases. ${ }^{91}$

None of the original returns made to the House of Lords before 1620 survives. Beginning in 1620/1, eighteen original returns to writs of habeas corpus in seventeen habeas proceedings in the House of Lords during the final five years of the reign of James I are in the Parliamentary Archives. ${ }^{92}$ These are the same seventeen House of Lords habeas cases from the reign of James I in which an original writ of habeas corpus is preserved in the Parliamentary Archives. The eighteen returns are on separate pieces of parchment ranging in size from three and one-half to twelve inches high and

${ }^{90}$ In re John Nanton (H.L. 1621), in 11 MHL 147, is the only case in which it specifically appears that a writ of habeas corpus issued in the case had not been executed and that therefore there would have been no occasion for a return to be made.

${ }^{91}$ See In re Richard Culpeper (H.L. 1624), in (1) 3 H.L.JouR. 421, and (2) $11 \mathrm{MHL}$ 163; in re Welsbourne Sill (H.L. 1624), in (1) 3 H.L.JouR. 386, and (2) 11 MHL 160; In re Sir Edward Osbaldeston (H.L. 1623/4), in (1) 3 H.L.JouR. 264, and (2) $11 \mathrm{MHL}$ 159; In re John Phillipps (H.L. 1623/4), in $11 \mathrm{MHL} 159$; in re George Hume (H.L. 1621), in MHL 157; In re Abraham Watts (H.L. 1621), in 11 MHL 157; In re Henry Lucye (H.L. 1621), in 3 H.L.JouR. 187, and (2) 11 MHL 157; In re William Whorewood (H.L. 1621), in (1) 3 H.L.Jour. 179, and (2) 11 MHL 157; In re Benjamin Crokey (H.L. 1621), in (1) 3 H.L.Jour. 173, and (2) $11 \mathrm{MHL} 156$; In re Richard Dyke (H.L.1621), in (1) 3 H.L.Jour. 170, and (2) 11 MHL 153; In re Originall Bellamye (H.L. 1621), in (1) 3 H.L.Jour. 156, and (2) $11 \mathrm{MHL}$ 152; In re John Nonne (H.L. 1621), in $11 \mathrm{MHL}$ 147; In re Francis Broade (H.L. 1621), in (1) 3 H.L.JouR. 96, and (2) $11 \mathrm{MHL} 146$; In re Sir Henry Fynes (H.L.1621), in 11 MHL 146; In re Solomon Browne (H.L. 1620/1), in 11 MHL 134; In re John Robinson (H.L. 1620/1), in 11 MHL 135; In re Sir David Wood (H.L. 1614), in 3 H.L.JouR. 712; In re Nathaniell Butler (H.L. 1607), in 2 H.L.Jour. 510; In re Thomas Musgrove (H.L. 1607), in 2 H.L.JouR. 498; In re Nicholas Reading (H.L. 1604), in 2 H.L.JouR. 313.

There are twenty-two returns in twenty-one cases because of the two returns in the case of In re Solomon Brown (H.L. 1620/1), in 11 MHL 134.

92 These returns are listed infra in Appendix 2.

There are eighteen returns in seventeen cases because of the two returns in the case of in re Solomon Brown (H.L. 1620/1), in 11 MHL 134. 
from nine to fourteen inches wide. ${ }^{93}$ To the extent they are legible; the returns reveal that the imprisoned person is in custody under civil arrest process.

On the return date of the writ of habeas corpus, the imprisoned person would be brought by his custodian into the chamber of the House of Lords ${ }^{94}$ and the written return presented to the House. The writ and the return would then be read out loud by the Clerk of the Parliaments. ${ }^{95}$

\section{Post-Return Procedure}

After the return had been made and the prisoner produced, the House of Lords, based on the contents of the writ and the return, ${ }^{96}$ but in some cases based also on the consideration of evidence, ${ }^{97}$

${ }^{93}$ See infra Appendix 2 , which in addition to listing the returns, gives the physical dimensions of the parchment documents on which these returns are written, as well as the Parliamentary Archives referencing designations of the returns.

Two of the eighteen returns are now illegible, while nine are partially illegible.

${ }^{94}$ The practice seems to have been that when escorted into the chamber of the House of Lords the prisoner would be placed at the bar. See, e.g., In re William Cowse (H.L. 1621), in 3 H.L.Jour. 170 (prisoner "brought to the Bar"); In re Richard Dyke (H.L. 1621), in 3 H.L.Jour. 170 (same); In re John Nanton (H.L. 1621), in 3 H.L.Jour. 133 (same); In re Sir David Wood (H.L. 1614), in 2 H.L.Jour. 712 (prisoner "was brought unto the Bar in this House").

${ }_{95}$ See, e.g., In re Francis Broade (H.L. 1621), in 3 H.L.Jour. 96 ("Writ, with the Return, being read by the Clerk (of the Parliaments]"); In re Sir David Wood (H.L. 1614), in 2 H.L.Jour. 712 ("Writ and Return were presently read in the House by the Clerk of the Parliament[s]") In re Nathaniell Butler (H.L. 1607), in 2 H.L.JouR. 510 ("Writ, and the Sheriff's Return thereon, was read by the Clerk of the Parliament[s]"); In re Thomas Musgrove (H.L. 1607), in 2 H.L.Jour. 498 ("Writ and Return were presently read in the House, by the Clerk of the Parliament[s]").

${ }^{96}$ See, e.g., In re Henry Lucye. (H.L. 1621), in 3 H.L.Jour. 187 ("The writ and the Return being read, the said Henry Lucy [sic] was delivered out of Prison"); in re Francis Broade (H.L. 1621), in 3 H.L.JouR. 96 ("Writ, with the Return, being read by the Clerk, [Broade] was discharged"); In re Nicholas Reading (H.L. 1604), in 2 H.L.Jour. 313 (after writ and return read, Reading discharged from custody).

${ }^{97}$ For example, in the case of In re Benjamin Crokey (H.L. 1621), in 3 H.L.Jour. 174 , in deciding to order Crokey discharged from custody, the House took into consideration not only the writ and the return, but also the habeas petition and a letter written by a member of the House. And in the case of in re William Whorewood (H.L. 1621), in 3 H.L.JouR.179, relief was granted based on the writ and the return, and on "the Lord Stafford avouching the said Whorewood to be his servant ...." 
would forthwith grant or deny habeas relief..$^{98}$ The Journal of the House of Lords often makes plain that the House was acting as a court of judicature when it granted habeas relief. ${ }^{99}$ The order of the House of Lords granting relief would be inserted in handwriting (and sometimes signed) by the Clerk of the Parliaments at the foot of the return. ${ }^{100}$ The relief granted invariably consisted of discharge from physical custody. ${ }^{101}$

\section{HABEAS PROCEEDINGS IN THE HOUSE OF COMMONS, 1603-1625}

\section{A. OVERVIEW}

In the reign of James I, the practice and procedure in habeas cases in the House of Commons closely resembled the practices and procedures used in the habeas cases in the House of Lords.

During that reign-when the House of Commons insisted it was and always had been a court of record ${ }^{102}$-there were a total of

${ }^{98}$ In almost all the twenty-nine habeas proceedings in which the House of Lords is known to have granted or denied relief, the order of the House discharging or remanding the prisoner was rendered the very day the return was made and the prisoner produced.

${ }^{99}$ See, e.g., In re Welsbourne Sill (H.L. 1624), in 3 H.L.Jour. 386 ("for that the Court found that [Sill] was arrested contrary to the Privileges of Parliament, he was discharged out of Prison"); In re George Belgrave (H.L. 1614), in 2 H.L.JouR. 695 ("by Order of the Court, [Belgrave] set at Liberty"); In re John Foster (H.L. 1607), in 2 H.L.Jour. 512 ("the Matter considered of by the Court, their Lordships thought meet, and so ORDERED, That the Prisoner should be forthwith discharged by Privilege of Parliament").

${ }^{100}$ An order of release is inserted in handwriting at the foot of fifteen of the Jacobean House of Lords habeas returns in the Parliamentary Archives, and on six of these returns the release order is signed "H. Elsynge." Henry Elsynge was the Clerk of the Parliaments during the last four years of James l's reign; see supra note 64.

${ }^{101}$ See, e.g., In re Benjamin Crokey (H.L. 1621), in 3 H.L.Jour. 174 ("the House ... did order the said Benjamyne [sic] Crokey to be discharged and delivered out of the said Prison"); In re Francis Broade (H.L. 1621), in 3 H.L.Jour. 96 (Broade "discharged and set at Liberty"); In re George Belgrave (H.L. 1614), in 2 H.L.JouR. 695 (Belgrave "by Order of the Court, set at Liberty, and discharged of the said Arrest").

102 Thus, "[i]n 1604, a committee of the lower house appointed to report on the liberties and privileges of the Commons, proclaimed the House of Commons'a Court of Record,' and 'so ever esteemed' ... " CARL WITtKe, The History of English Parliamentary Privilege 94 (1921). 
seven separate habeas corpus proceedings in the House of Commons of the High Court of Parliament. ${ }^{103}$ One of the habeas cases was in 1604; two were in 1605/6; two were in 1606/7; one was in 1610; and the final case was in 1614.

In four of the seven cases the imprisonment complained of was the result of civil arrest process. In the seven cases, a total of nine or ten writs of habeas corpus were issued, while six returns were made to those writs. Habeas relief was granted in at least four (57\%) of the seven cases.

Four of the seven habeas proceedings in the House of Commons in the reign of James I involved members of the House. One of these proceedings involving a member, In re Sir Thomas Shirley, ${ }^{104}$ decided early in the reign, is the most celebrated habeas corpus case ever heard in the High Court of Parliament (although scholars discussing Shirley have unintentionally tended to emphasize the parliamentary privilege from arrest issue and to downplay the significant fact that Shirley is a seminal and classic parliamentary habeas corpus proceeding).

None of the original parchment documents in the seven habeas proceedings in the House of Commons in the reign of James I is in the Parliamentary Archives-not a single habeas petition, writ of habeas corpus, or return to a habeas writ. ${ }^{105}$ Most of what is known

${ }^{103}$ These seven cases, with full citations, are listed in chronological order infra in Part B of Appendix 1, which also provides certain background information on the cases. Whenever one of these cases is cited in a footnote, only the applicable portion of the citation is given unless the full citation is appropriate.

${ }_{104}$ In re Sir Thomas Shirley (H.C. 1603/4, 1604), in (1) 1 H.C.JouR. 149, 155, $167-$ $68,171,200,202-03,204-05,205-06,206-07,208,209-10,210-11,211,213,215$, and (2) 1 HATSELL 157-60. For more on Shirley, see supra notes 5, 8-13 and accompanying text, and infra notes 106,118,127,128,133, 137, 144 and accompanying text.

105 The original but now missing documents relating to habeas proceedings in the Jacobean House of Commons were among the numerous records stored away by the House of Commons but destroyed by the great fire that burned down the medieval Palace of Westminster on the night of October 16, 1834. See MAURICE F. Bond, Guide to tHe Recoros of PARLIAMENT 4 (1971) ("almost the entire range" of the archives of House of Commons were "consumed" by the 1834 fire "with the vital exception of the Commons Journals"). "The House of Lords archive," on the other hand, "survived the fire of 1834. This was due in part to the isolated position of the Jewel Tower where the main series of [House of Lords] records had been preserved, but also in part to the efforts of a Lords clerk, Mr. Stone Smith, who threw out of the blazing windows of the main building into Old Palace Yard many hundreds of bundles of other Lords papers that had not been transferred to the Jewel Tower." Id. 
about these seven habeas proceedings derives from three sources: (1) the Journal of the House of Commons; (2) manuscripts published and annotated by Elizabeth Reid Foster in the second volume of her 1966 book Proceedings in Parliament, 1610; and (3) the first volume of John Hatsell's Precedents of the Proceedings in the House of Commons. This does not mean, however, that the exact contents of every one of the original documents associated with these proceedings is unknown. The Journal of the House of Commons prints verbatim five warrants of the Speaker of the House of Commons, addressed to the Clerk of the Crown in Chancery, directing issuance of a writ of habeas corpus. It also prints verbatim two of the writs of habeas corpus issued pursuant to these warrants, as well as the returns to those two habeas writs.

\section{B. PRACTICE AND PROCEDURE}

\section{Commencement of Proceeding}

How were habeas corpus proceedings commenced in the House of Commons during the reign of James I?

Turning to the four habeas proceedings involving a member of Parliament, the Shirley case began with a "Motion tending to Matter of Privilege" proposed to the House by an unnamed member and seconded by a named member); ${ }^{106}$ another case began when a member presented to the House a written petition of the imprisoned member which the prisoner had previously delivered to the sergeant at arms of the House; ${ }^{107}$ a third case began when a member moved the House that another member stood committed to prison and prayed the direction of the House, ${ }^{108}$ and in the fourth case the currently available information does not indicate how the member's imprisonment was brought to the attention of the House. ${ }^{109}$

${ }^{106}$ See In re Sir Thomas Shirley (H.C. 1603/4), in 1 H.C. Jour. 149. 1 HATSELL 157 calls the privilege motion a "complaint."

${ }^{107}$ See In re Roger Brereton (H.C. 1605/6), in 1 H.C. JouR. 262. The contents of this petition are unknown, and it is uncertain whether the petition was a habeas petition addressed to the House of Commons.

${ }^{108}$ See In re Sir William Bamfeild (H.C. 1614), in 1 H.C.Jour. 458.

${ }^{109}$ See In re Sir Vincent Skinner (H.C. 1610), in 2 Foster 306. There is simply nothing in the account of this case indicating how it commenced in the House of Commons. 
With respect to the three habeas cases involving the imprisonment of a servant of a member of the House of Commons, one of them began when a member moved in the House a breach of privilege because his coachman had been committed to Newgate prison; ;10 the second began when the House was informed of the servant's imprisonment by an unknown person (presumably a member of the House); $; 11$ and the third case began when the Speaker of the House "taketh Knowledge of an Information given him, touching the Arrest" of the servant. ${ }^{112}$

Since only one of the seven habeas cases in the House of Commons in the reign of James $I$ is known to have involved a written petition, and since, moreover, it is unknown whether that petition was in fact a habeas petition addressed to the House, it appears that during the reign habeas proceedings in the House may have not usually been instituted via a written habeas corpus petition submitted to the House. Rather they seem to have typically been commenced when the House was verbally informed by one of its members of the imprisonment allegedly violative of parliamentary privilege.

\section{Issuance of Writ}

Once a habeas claim of imprisonment in violation of the parliamentary privilege from arrest was brought to the attention of the House of Commons verbally or by other procedure, the House tended to follow either of two courses of action. It might without delay approve issuance of a writ of habeas corpus, as occurred in three cases. ${ }^{113}$ Alternatively, it might refer the imprisonment issue

${ }^{110}$ See In re Sir Edwyn Sandy's Servants (H.C. 1605/6), in 1 H.C.Jour. 270.

${ }^{111}$ See In re Thomas Finch (H.C. 1606/7), in 1 H.C.Jour. 332.

${ }^{112}$ See in re Nicholas Hawkins (H.C. 1606/7), in 1 H.C.Jour. 338.

${ }^{133}$ See in re Nicholas Hawkins (H.C. 1606/7), in 1 H.C. Jour. 338 (on day House informed of arrest of Hawkins, servant of member, "Order [was] given, to direct a Warrant for an Habeas Corpus for the Party Arrested"); In re Thomas Finch (H.C. 1606/7), in 1 H.C. Jour. 332 ("The House was this Day informed, that Tho. Finch[,] Servant to ... [o]ne of the Burgesses[,] ... was arrested in an Action of Debt .... This being conceived to be a great Contempt to the Privilege of the House, it was ordered, that an Habeas Corpus should be awarded"); In re Sir Thomas Shirley (H.C. 1603/4), in 1 H.C. JOUR. 149 (on day it was informed of arrest of one of its members, "the House, in affirmation of their own Privilege, assented and Ordered, That a Warrant ... should be directed, under the Hand of Mr. Speaker, to the Clerk of the Crown, for the granting of a Writ of Habeas Corpus"). 
to a committee and thereafter approve issuance of the habeas writ based on the report of the committee, as happened in two cases. In two other cases, ${ }^{114}$ however, the circumstances under which authorization for the writ was granted are, based on current information, unknown. ${ }^{115}$ In its seven habeas proceedings, the House approved issuance of a writ of habeas corpus a total of ten times. ${ }^{116}$

Like the House of Lords, the House of Commons left it to the Crown Office in Chancery to actually issue the writs of habeas corpus it had ordered. After the House of Commons had approved an order directing issuance of a writ of habeas corpus, the practice was for the Speaker of that House to sign a warrant addressed to the Clerk of the Crown in Chancery commanding issuance of a habeas writ for the production of the prisoner named in the warrant. ${ }^{117}$ In the reign of James I it explicitly appears from the Journal of the House of Commons that five warrants were signed in the habeas cases in the House-four warrants in the Shirley case ${ }^{118}$ and one warrant in another case. ${ }^{119}$ In four cases ${ }^{120}$ there is no mention of a Speaker's warrant, but it is a certainty that one such warrant must have been signed in each of these cases because in each a habeas

${ }^{114}$ See In re Sir William Bamfeild (H.C. 1614), in 1 H.C.Jour. 458, 464 (on Apr. 9 , issue of imprisonment of Bamfeild is referred to committee on privileges; on Apr. 14, habeas corpus ordered); In re Roger Brereton (H.C. 1605/6), in 1 H.C. Jour. 26263, 267 (on Feb. 3, issue of imprisonment of Brereton referred to committee; on Feb. 13, "Habeas Corpus for Mr. Brereton").

${ }^{115}$ See In re Sir Vincent Skinner (H.C. 1610), in 2 FOSTER 306; In re Sir Edwyn Sandy's Servants (H.C. 1605/6), in 1 H.C.JouR. 270 . In both these cases all we know about the authorization for the writ is that such authorization must have occurred, because subsequently a writ of habeas corpus did in fact issue in each case.

116 In addition to the seven authorizations mentioned supra at notes 113-115 and accompanying text, the House authorized the writ three additional times in the Shirley case (where a total of four habeas writs were issued). For these three authorizations, see 1 H.C.Jour. 167, 200, 210.

${ }^{117}$ The Clerk of the Crown in Chancery and his deputy are, it will be recalled, "officers of both the House of Lords and of the House of Commons." ERskine MAY's Treatise on the Law, Privileges, Proceedings and Usage of Parliament 191 (C.J. Boulton ed., 21st ed. 1989) (footnote omitted).

${ }^{118}$ See in re Sir Thomas Shirley (H.C. 1603/4, 1604), in 1 H.C.Jour. 149, 167, 200, 210.

${ }^{119}$ See In re Thomas Finch (H.C. 1606/7), in 1 H.C.Jour. 332.

${ }^{120}$ See In re Sir William Bamfeild (H.C. 1614), in (1) 1 H.C.Jour. 458, 464, 466; In re Sir Vincent Skinner (H.C. 1610), in 2 FosteR 306-08; In re Sir Edwyn Sandy's Servants (H.C. 1605/6), in 1 H.C.JouR. 270, 272, 272-73; In re Roger Brereton (H.C. 1605/6), in 1 H.C.Jour. 262-63, 267, 269. 
writ did issue by order of the House of Commons-and a habeas writ returnable to the House of Commons could be issued only pursuant to a Speaker's warrant. In one case there may or may not have been a Speaker's warrant. ${ }^{121}$ Thus, there had to have been nine, and there may possibly have been ten, warrants for issuance of a writ of habeas corpus in at least six and perhaps all seven of the habeas proceedings in the House during the reign.

The Journal of the House of Commons sets forth verbatim five of these warrants, which are printed in the entries for March 22, $1603 / 4 ; ;^{122}$ April 11, 1604; ;23 May 7, 1604; $;^{124}$ May 14, 1604;:125 and Feb. $10,1606 / 7,{ }^{126}$ respectively. The first four of these five warrants were in the Shirley case alone. All five warrants are in English. All five warrants follow a standard form. The first, relating to the imprisonment of Sir Thomas Shirley, is set forth in the margin. ${ }^{127}$

Once the Speaker's warrant had been signed and delivered, the Crown Office in Chancery would promptly prepare and issue the

${ }^{121}$ See In re Nicholas Hawkins (H.C. 1606/7), in (1) 1 H.C.Jour. 338, and (2) 1 HATSELL 162, where the House approved an order for a warrant directing issuance of a writ of habeas corpus but the warrant may in fact never have been prepared, since the habeas proceeding was terminated by mediation on the very day it was instituted in the House.

1221 H.C.Jour. 149 (Mar. 22, 1603/4).

${ }^{123} 1$ H.C.Jour. 167 (Apr. 11, 1604).

1241 H.C.Jour. 200 (May 7, 1604).

1251 H.C.Jour. 210 (May 14, 1604).

${ }^{126} 1$ H.C.Jour. 332 (Feb. 10, 1606/7).

${ }^{127}$ It is this Day Ordered and required by the Commons House of Parliament, that a Writ of Habeas Corpus be awarded, for the Bringing of the Body of Sir Thomas Shirley Knight, one of the Members of this House, and now Prisoner in the Fleet, into the said House, upon Tuesday next, at Eight a Clock in the Morning, according to the ancient Privilege and Custom in that Behalf used. And this shall be your Warrant.

Your loving Friend,

Edward Phelips, Speaker.

Directed,

To my very loving Friend,

Sir George Coppyn Knight,

Clerk of the Crown in his Majesty's High Court of Chancery.

1 H.C.Jour. 149 (Mar. 22, 1603/4). Sir Edward Phelips was Speaker of the House of Commons from March 1603/4 to February 1610/1. See DaVID L. SMITH, THE STUART PARLIAMENTS 1603-1689, at 243 (1999).

This warrant is the first of the four habeas warrants signed by the Speaker in regard to the imprisonment of Sir Thomas Shirley. 
writ of habeas corpus, which would be signed by the Clerk of the Crown Office in Chancery. The writ was in Latin and returnable to the House of Commons.

From the Journal of the House it is evident that four habeas writs were issued in the Shirley case, ${ }^{128}$ and that one habeas writ was issued in each of four other cases. ${ }^{129}$ Furthermore, a writ of habeas corpus was issued in a habeas case in the House of Commons that is not mentioned in the Journal of the House. ${ }^{130}$ However, in the seventh case, which was settled by mediation the day the House authorized issuance of the writ, it may be that the settlement occurred before the writ actually issued. ${ }^{131}$ Thus, at least nine and possibly ten writs of habeas corpus were issued by order of the House of Commons in the reign of James I. The number of habeas writs issued by order of the House of Commons therefore conforms to the number of Speaker's warrants commanding issuance of a habeas writ.

Two of these House of Commons writs of habeas corpus are printed verbatim in the Journal of the House. One of them, issued pursuant to a warrant of the Speaker signed May 7, 1604, 132 was the third habeas writ issued in the Shirley case, and is set forth in the margin. ${ }^{133}$ The other, and almost identical, habeas writ, issued 210.

${ }^{128}$ See In re Sir Thomas Shirley (H.C. 1603/4, 1604), in 1 H.C.Jour. 149, 167, 203,

${ }^{129}$ See In re Sir William Bamfeild (H.C. 1614), in 1 H.C.Jour. 464, 466; In re Thomas Finch (H.C. 1606/7), in 1 H.C.Jour. 334; In re Sir Edwyn Sandy's Servants (H.C. 1605/6), in 1 H.C.Jour. 270; In re Roger Brereton (H.C. 1605/6), in 1 H.C.JouR. 269.

${ }^{130}$ See In re Sir Vincent Skinner (H.C. 1610), in 2 FOSTER 308 n.3 ("'Sir Vincent Skinner . . . was released by habeas corpus ...'”) (quoting unpublished manuscript).

${ }^{131}$ See In re Nicholas Hawkins (H.C. 1606/7), in 1 H.C.Jour. 338, 339. The matter of the imprisonment was brought to the attention of the House on Feb. 20,1606/7, and on that day the House made an order "to direct a Warrant for an Habeas Corpus for the Party Arrested." Id. Later that same day, however, "[t]he matter touching the Arrest of Nicholas Hawkins, Servant to Sir Warwick Heale ... [was] reported to be stayed and appeased by Mediation," id., and there is no indication that the writ of habeas corpus ever in fact issued.

132 See 1 H.C.Jour. 200 (May 7, 1604).

${ }^{133}$ Jacobus, Dei gratia, Angliae, Scotiae, Franciae, et Hiberniae Rex, fidei Defensor, etc. Gardiano prisonae nostrae de la Fleete, Salutem. Praecipimus tibi, quod habeas coram nobis, in praesenti Parliamento nostro, apud Westm. in die Martis, octavo die instantis mensis Maii, circa horam octavam ante meridiem ejus- 
pursuant to a Speaker's warrant signed on February 10, 1606/7,134 involved an imprisoned servant, Thomas Finch. ${ }^{135}$ These two habeas writs issued by order of the House of Commons are plainly similar in form to the habeas writs issued by order of the House of Lords during the reign.

\section{Return to Writ}

The writ of habeas corpus mandated that the custodian have the imprisoned person "coram nobis, in praesenti Parliamento nostro" [before us, in our present Parliament]. This terminology was understood to mean that the prisoner had to be brought before the House of Commons (as opposed to the House of Lords). The writ was thus returnable to the House of Commons itself. Like a writ of

dem diei, corpus Thomae Shirley militis, capt. et in prisona nostra, sub custodia tua, ut dicitur, detent, quocunque nomine, aut cognomine, idem Thomas censeatur, una cum causa captonis et detentionis ejusden Thomae, ad respondendum super hiis, quae sibi tunc ibidem objicientur, et ad faciendum ulterius, et recipiendum, quod per nos, in Parliamento nostro praedicto Consideratum et ordinatum fuerit: Et hoc nullatenus omittas, sicut nobis inde respondere volueris. Et habeas ibi hoc Breve. Teste meipso apud Westm. septimo die Maii, anno regni nostri, Angliae, Franciae, et Hiberniae, secundo, et Scotiae, tricesimo septimo.

Coppin.

[James, By the Grace of God, King of England, Scotland, France, and Ireland, Defender of the Faith, etc. To the Keeper of our prison of the Fleet. Greeting. We command you that you have before us, in our present Parliament, at Westminster, on Tuesday the eighth day of the present month of May, around the eighth hour in the morning of the said day, the body of the Thomas Shirley, knight, detained in our prison under your custody, as it is said, by whatsoever name Thomas may be called or known, together with the cause for the arrest and detention of the said Thomas, and in addition there must be a response to that which then and there will be objected, and further to undergo and receive whatever we, in our said Parliament, shall have considered and ordered: And this by no means omit, as thenceforth you will have wished you answered to us. And have there this writ. Witness myself, at Westminster, the seventh day of May, in the second year of our reign in England, France, and Ireland, and in Scotland, the thirty-seventh.]

1 H.C.Jour. 203 (May 8, 1604). Sir George Coppin, who signed the writ, was the Clerk of the Crown in Chancery in 1604. See supra note 82.

The verbatim text of this same habeas writ also appears by editorial or printing mistake at 1 H.C.Jour. 149 (Mar. 22, 1603/4), where the text of the case's first habeas writ, which was authorized that on date, and which should have been entered there, has been erroneously omitted.

${ }^{134}$ See 1 H.C.Jour. 332 (Feb. 10, 1606/7).

${ }^{135}$ See 1 H.C.JOUR. 334 (Feb. 13, 1606/7). 
habeas corpus in behalf of the House of Lords, the writ also required the custodian to provide "una ... causa captionis et detentionis" [the cause for the arrest and detention]. Once he had been served with a writ of habeas corpus, therefore, the custodian was required to bring the imprisoned person into the chamber of the House of Commons at the time specified in the writ and to make a return giving an explanation for the imprisonment.

The return would be in writing, in Latin, and signed by the custodian.

After the return had been made, the usual practice seems to have been that the writ of habeas corpus (and presumably the return also) would be read out loud by the Clerk of the House of Commons. ${ }^{136}$ In the reign of James I the Journal of the House of Commons specifically refers to four habeas returns-two in the Shirley ${ }^{137}$ case and one in each of two other cases. ${ }^{138}$ Furthermore, it is nearly certain that a return was made in each of two additional cases. ${ }^{139}$ In the remaining two cases it is highly doubtful that a re-

${ }^{136}$ See, e.g., In re Thomas Finch (H.C. 1606/7), in 1 H.C.Jour. 334 ("The Writ of Habeas Corpus... was returned and read by the Clerk"); In re Roger Brereton (H.C. 1605/6), in 1 HATSELL 132 ("a Writ of Habeas Corpus is ordered for Mr. Brereton, which is returned and read in the House"); In re Sir Thomas Shirley (H.C. 1603/4), in 1 H.C.JouR. 155 ("The Writ and Return was [sic] read by the Clerk").

During James I's reign, there were three Clerks of the House of Commons: Ralph Ewens, who served from 1603 to 1611; William Pynches, who served from 1611 to 1612; and John Wright, who served from 1612 to 1633 . DaVID L. SMITH, THE STUART PARLIAMENTS 1603-1689, at 246 (1999).

For the history and present functions of the office of Clerk of the House of Commons, see AN EnCYCLOPEDIA OF PARLIAMENT 134-36 (Norman Wilding \& Philip Laundy eds., 4th ed. 1971); see also Erskine May's Treatise on The Law, Privileges, Proceedings AND USAGE OF PARLIAMENT 188-89 (C.J. Boulton ed., 21st ed. 1989) (examining current duties of Clerk of the House of Commons).

${ }^{137}$ See In re Sir Thomas Shirley (H.C. 1603/4, 1604), in 1 H.C.Jour. 155, 203. In this case, it will be remembered, four writs of habeas corpus were issued. The returns were made to the first and the third of these habeas writs. There do not appear to have been returns made to the second and fourth writs.

${ }^{138}$ See In re Thomas Finch (H.C. 1606/7), in 1 H.C.Jour. 334 (setting forth text of return); In re Roger Brereton (H.C. 1605/6), in 1 H.C.Jour. 269 ("Writ returned.").

${ }^{139}$ See In re Sir William Bamfeild (H.C. 1614), in 1 H.C.Jour. 464, 466, and In re Sir Vincent Skinner (H.C. 1610), in 2 Foster 306-08. In each of these cases a writ of habeas corpus was issued and the imprisoned person brought before the House pursuant to the writ. Almost certainly a return was made in these cases at the time the prisoner was produced before the House. 
turn was made. ${ }^{140}$ Thus, a total of six returns seem to have been made in five of the habeas cases in the House, while there were likely no returns in the two other cases.

From the returns and other available information it appears that in three of the seven habeas cases the imprisonment was not attributable to civil arrest process. One of these three cases involved a member of the House committed by the Lord Chancellor, ${ }^{141}$ while the other two cases involved respectively a single servant committed for contempt by the Court of King's Bench, ${ }^{142}$ and several servants committed without bail by a justice of the peace. ${ }^{143}$

The Journal of the House of Commons prints verbatim two of the returns. The first of these returns, set forth in the margin, ${ }^{144}$ was in response to the third habeas writ issued in the Shirley case. Unusually, this return does not announce the production of the imprisoned person or furnish any explanation for the person's custody. Instead it informs the House of Commons that the habeas writ was served tardily, and bluntly states that the prisoner is not being produced. The second of the returns, from a separate parliamentary

${ }^{140}$ See In re Nicholas Hawkins (H.C. 1606/7), in 1 H.C.Jour. 338, 339; In re Edwyn Sandy's Servants (H.C. 1605/6), in 1 H.C.Jour. 270. In Hawkins, the proceeding was terminated by mediation on the day it was filed in the House, no writ of habeas corpus may ever have actually issued, and almost certainly no return was made. In Sandys, where there is no mention of a return, the House focused more on punishing the judge who had imprisoned the servants than on freeing the servants, and the entry for the case in the Journal of the House of Commons "is so very confused," 1 HATSELL 133.

${ }^{141}$ See In re Sir William Bamfeild (H.C. 1614), in 1 H.C.Jour. 458.

${ }^{142}$ See in re Roger Brereton (H.C. 1605/6), in 1 H.C.Jour. 262.

${ }^{143}$ See In re Edwyn Sandy's Servants (H.C. 1605/6), in 1 H.C.Jour. 270.

${ }^{144}$ Responsum Johannis Trench armigeri, Gardiani: Ego Johannes Trench armiger, Gardianus prisonae Domini Regis de le Fleet, Domino Regi in Parliamento suo certifico, quod istud Breve adeo tarde mihi advenit, quod corpus infra nominati Thomae Shurley, ad diem, horam, et locum infra content. habere non potui, prout interius mihi praecipitur.

[Response of John Trench, knight, Warden: I, John Trench, knight, Warden of the Lord King's prison of the Fleet, certify to the Lord King in his Parliament, because your Writ was brought to me so late, I am unable to have the body of Thomas Shirley, named in the writ, by the day, hour, and place, as I am ordered within the writ.]

1 H.C.Jour. 203 (May 8, 1604). 
habeas proceeding, is longer and more typical of habeas returns. It announces the production of the prisoner, a parliamentary servant named Thomas Finch, and it includes in an attachment a copy of the capias ad satisfaciendum writ pursuant to which Finch was confined. ${ }^{145}$

\section{Post-Return Procedure}

There is little information on the procedures followed after the writ and return had been read out loud in the five cases where it appears there was a return to a writ of habeas corpus. In one of these cases, involving a servant, the House of Commons proceeded to hear from the servant and from the member employing the servant, and then ordered the servant released. ${ }^{146}$ In two of the cases all we know is that after the return was made the imprisoned person was released from custody. ${ }^{147}$ In another of the cases what happened after the return is unknown. ${ }^{148}$ Finally, in the Shirley case, where there were four writs of habeas corpus but returns to only the first and third of the habeas writs, those two returns were only preliminaries to the final disposition of the case following the issuance of the subsequent fourth habeas writ.

Overall, habeas relief-which always consisted of discharge from physical custody-is known to have been granted in four of the seven cases. ${ }^{149}$ In two cases relief may have been granted; ${ }^{150}$ and in the seventh case, the proceeding was brought to a close by mediation, with relief being neither granted nor denied. ${ }^{151}$ Thus, it is possible that relief was granted in six of the seven cases. In not a single case is relief known to have been denied.

\footnotetext{
${ }^{145}$ See 1 H.C.Jour. 334 (Feb. 13, 1606/7).

${ }^{146}$ See In re Thomas Finch (H.C. 1606/7), in (1) 1 H.C.Jour. 334, and (2) 1 HATSELL 161.

${ }^{147}$ See In re Sir Vincent Skinner (H.C. 1610), in 2 FosTER 306-08; In re Roger Brereton (H.C. 1605/6), in (1) 1 H.C.Jour. 269, and (2) 1 HATSELL 132.

${ }^{148}$ See in re Sir William Bamfeild (H.C. 1614), in (1) 1 H.C.Jour. 466, and (2) 1 HATSELL 133.

${ }^{149}$ See infra Part B of Appendix 1.

$150 / d$.

$151 / d$.
} 


\section{CONCLUSION}

In the reign of James I the High Court of Parliament was not only a court of judicature but a habeas court-a judicial tribunal which entertained habeas corpus petitions, ordered issuance of writs of habeas corpus, litigated habeas corpus proceedings, and granted habeas corpus relief. The Court of Chancery and the three common law courts of King's Bench, Common Pleas, and Exchequer, were habeas tribunals, to be sure, but so was the High Court of Parliament, which exercised its habeas jurisdiction through each of its Houses acting separately and independently. The scholars ${ }^{152}$ who assert or assume that the number of English habeas courts was four are flat wrong. There were five, not four.

Our understanding of the history of the English writ of habeas corpus, and of the history of Parliament, needs revision in two additional respects.

To begin, traditional scholarship on the topic of Parliament and habeas corpus must be reexamined because it fails to acknowledge the existence of parliamentary habeas corpus proceedings. This scholarship may be divided into three categories. First, there is the literature on the post-1600 habeas statutes enacted by or proposed in Parliament, such as the Habeas Corpus Act of $1679,{ }^{153}$ the never-

152 See, e.g., 3 William Blackstone, CommentaRies on the LaWs of England 131-32 (photo. reprint 1966) (Oxford, Clarendon 1768); WiLlaM S. CHURCH, A TrEATISE OF THE Writ of HABEAS CoRpus 54 (San Francisco, A.L. Bancroft 1884); 9 WILlIAM HoldsWORTH, A History of English LaW 115-16 (3d ed. 1944); Rollin C. Hurd, A Treatise on the Right of Personal Liberty and on the Writ of Habeas Corpus 147 (Albany, W. C. Little 1858); R.J. Sharpe, The law of Habeas Corpus 6 (2d ed. 1989); Donald E. Wilkes, Jr., Federal Postconviction Remedies and Relief 62 (1996).

153 1679, 31 Car. 2, c. 2 (Eng.). The 1679 Act, "with respect to pretrial imprisonment on criminal charges, reformed habeas corpus procedures, expanded and clarified the authority of the courts and judges empowered to issue the writ, guaranteed, under specified circumstances, the rights to pretrial bail and to a speedy trial, and prohibited transporting prisoners beyond the seas where the writ did not run[.]" Donald E. Wilkes, Jr. Federal Postconviction Remedies and Relief 61 (1996). The 1679 Act is examined in Paul D. Halliday, Habeas Corpus: From England TO EMPIRE 237-46 (2010). For articles on the renowned 1679 statute, see Helen A. Nutting, The Most Wholesome Law-The Habeas Corpus Act of 1679, 65 AM. HIST. Rev. 527 (1960); Godfrey Davies \& Edith L. Klotz, The Habeas Corpus Act of 1679 in the House of Lords, 3 HUNTINGTON LIBR. Q. 469 (1940); see also Stephen I. Vladeck, The New Habeas Revisionism, 124 Harv. L. Rev. 941, 953-56 (2011) (book review) (discussing 1679 Act). 
enacted Habeas Corpus Bill of $1758,{ }^{154}$ the Habeas Corpus Act of $1816,{ }^{155}$ and the Habeas Corpus Act of $1862 .{ }^{156}$ Second, there is the literature on habeas suspension under the various habeas corpus suspension statutes enacted by Parliament between 1689 and 1881. ${ }^{157}$ Third, there is the literature that investigates the extent to

154 "The object of the bill was to extend the [Habeas Corpus] Act of 1679 so as to give the benefit of the writ of Habeas Corpus ad subjiciendum, as improved by that Act, to persons who were imprisoned otherwise than on a criminal charge." 9 WILLIAM HOLDSWORTH, A HISTORY OF ENGLISH LAW 119 (3d ed. 1944). For a key essay on the 1758 bill, which passed the House of Commons but failed in the House of Lords, see Barbara Wilcie Kern, The English High Judiciary and the Politics of the Habeas Corpus Bill of 1758, in LAW AS Culture \& Culture As LaW 147 (Hendrik Hartog \& William E. Nelson eds., 2000); see also Kevin Costello, Habeas Corpus and Military and Naval Impressment, 29 J. LEG. HIST. 215, 218-34 (2008) (surveying legislative history of 1758 habeas bill); James Oldham \& Michael J. Wishnie, The Historical Scope of Habeas Corpus and INS v. St. Cyr, 16 GEO. IMmiGR. L.J. 485, 487-95 (2002) (examining background and context of 1758 bill).

${ }_{155} 1816,56$ Geo. 3, c. 100 (Eng.). This statute provided, among other things, that "the [Habeas Corpus] Act of 1679 should apply to persons deprived of their liberty otherwise than by reason of a charge of crime, unless they were imprisoned for debt or on process in a civil suit ..." 9 WILLIAM HOLDSWORTH, A HISTORY OF ENGLISH LAW 121 (3d ed. 1944). "The Act of 1816 was in substance the same as the bill of 1758 ...." R.J. Sharpe, The LAW OF Habeas CoRpus 68 n.28 (2d ed. 1989). Surprisingly, there do not appear to be any scholarly articles devoted solely to the 1816 statute. For discussion of the 1816 statute in treatises, see Paul D. Halliday, Habeas Corpus: From England to Empire 246 (2010); 9 William Holdsworth, A History OF ENGLISH LAW 119-22 (3d ed. 1944); R.J. Sharpe, The Law of Habeas Corpus 68-71 (2d ed. 1989).

$1561862,25 \& 26$ Vict., c. 20 (Eng.). This statute "prohibits the English courts from granting writs of habeas corpus to persons imprisoned in a colony or foreign dominion if there are local courts in the colony or dominion with authority to grant writs of habeas corpus ..." Donald E. WiLKes, JR., Federal Postconviction Remedies AND ReLIEF 61 (1996). For an article on the 1862 statute, see Note, On the Power of the English Courts to Issue the Writ of Habeas to Places Within the Dominions of the Crown, But Out of England, 8 JuRiD. Rev. 157 (1896); see also R.J. Sharpe, THE LAW OF HABEAS CoRpus 189-91 (2d ed. 1989) (discussing 1862 habeas statute).

157 "Between 1689, when Parliament first suspended habeas corpus, and 1881, when the final suspension statute was passed, Parliament enacted over forty habeas corpus suspension statutes. The suspension statutes, which usually were temporary acts expiring after one year unless continued by another Act of Parliament, were enacted during times of actual or threatened rebellion or invasion and typically provided that imprisoned persons charged with high treason or certain related offenses could be kept in pretrial custody and could not be bailed or placed on trial." Donald E. Wilkes, JR., Federal Postconviction Remedies and Relief 61 (1996) (footnote omitted). For an impressive recent article on the English suspension statutes and their implementation, see Paul D. Halliday \& G. Edward White, The Suspension Clause: English Text, Imperial Contexts, and American Implications, 94 VA. L. Rev. 575, 613-28, 644-51 (2008); see also Clarence C. Crawford, The Suspen- 
which the English common law courts are authorized to grant habeas relief to persons imprisoned by order of a House of Parliament. ${ }^{158}$ This Article creates-and simultaneously contributes to-

sion of the Habeas Corpus Act and the Revolution of 1689, 30 ENG. HIST. REv. 613 (1915) (discussing the first three habeas suspension statutes, all enacted in 1689 in the immediate aftermath of the Glorious Revolution); Amanda L. Tyler, The Forgotten Core Meaning of the Suspension Clause, 125 HARV. L. REv. 901, 934-54 (2012) (examining parliamentary suspensions of habeas corpus from 1689 to 1783).

${ }^{158}$ For an important article examining the degree to which common law courts may issue habeas relief from parliamentary commitments, see Amnon Rubinstein, Habeas Corpus as a Means of Review, 27 MoD. L. REv. 322, 325-26 (1964); see also AMNON RUBINSTEIN, JURISDICTION AND lLLEGALITY 109-110 (1965) (surveying habeas review by common law courts of parliamentary commitments).

Usually common law court habeas corpus review of Parliamentary commitments has occurred in the context of cases where a House of Parliament has ordered the imprisonment for contempt or breach of privilege. In these habeas cases in the common law courts the imprisoned person challenging imprisonment ordered by a House of Parliament sometimes was a member of that House, but usually was a nonmember and never a parliamentary servant.

The leading cases on the power of a common law court to review, via habeas corpus, imprisonment ordered by a House of Parliament are: Case of the Sheriff of Middlesex, 113 Eng. Rep. 419 (Q.B. 1840) (commitment of nonmember by House of Commons for contempt and breach of privilege; relief denied); Hobhouse's Case, 106 Eng. Rep. 716 (K.B. 1820) (commitment of nonmember by House of Commons for breach of privilege; relief denied); $R$. v. Flower, 101 Eng. Rep. 1408 (K.B. 1799) (commitment of nonmember by House of Lords for breach of privilege; relief denied); Brass Crosby's Case, 95 Eng. Rep. 1005, 96 Eng. Rep. 441 (C.P. 1771) (commitment of nonmember by House of Commons for breach of privilege; relief denied); Alexander Murray's Case, 95 Eng. Rep. 629 (K.B. 1751) (commitment of nonmember by House of Commons for contempt; relief denied); R. v. Paty, 90 Eng. Rep. 1189, 91 Eng. Rep. 431, 92 Eng. Rep. 232 (Q.B. 1705) (commitment of nonmember by House of Commons for contempt and breach of privilege; relief denied); Earl of Shaftsbury's Case, 86 Eng. Rep. 792, 6 Howel's StATE TrIaLS 1269 (K.B. 1677) (commitment of member of House of Lords for contempt; relief denied).

The general rule arising from these cases is that common law courts may not grant habeas corpus relief to persons committed to imprisonment by a House of Parliament, except in the extremely unlikely event that the order or warrant directing the imprisonment shows on its face that the imprisonment is unlawful. See, e.g., Erskine May's Treatise on the Law, Privileges, Proceedings and Usage of Parliament 115-20, 196-98 (Barnett Cocks ed., 18th ed. 1971) (stating that, under the modern view, if a parliamentary warrant states the particular facts forming the basis for the commitment, the courts no longer disclaim any power to inquire into the commitment, and that "if the causes of commitment are stated on the warrant, and appear to be in respect of no established privilege, the courts have claimed the right to examine their sufficiency [in habeas corpus proceedings]"); Amnon Rubinstein, Habeas Corpus as a Means of Review, 27 Mod. L. Rev. 322, 326 (1964) (in cases of commitment for contempt or breach of privilege, Parliament need not specify the grounds for the commitment, and the mere existence of the warrant 
a needed fourth category of scholarship on the topic of Parliament and the writ of habeas corpus: writings on habeas corpus proceedings in the High Court of Parliament itself. ${ }^{159}$

There must also be a reexamination of scholarly historical literature on the High Court of Parliament as a judicial tribunal, for this literature, like scholarship on the topic of Parliament and habeas corpus, traditionally fails to recognize that the High Court of Parliament sometimes functioned specifically as a habeas court. ${ }^{160}$

ousts the jurisdiction of the courts; nevertheless, if Parliament elects to specify the grounds for the commitment, and if those grounds do not bear out the commitment or cannot be considered to amount to contempt or breach of privilege, then the courts may grant the writ of habeas corpus even though Parliament ordered the commitment); see also Gosset v. Howard, 116 Eng. Rep. 158 (Exch. Chamber 1847) (arrest warrant for contempt issued by House of Commons must be construed as a warrant issued by a superior court; here, the warrant, not appearing on its face to be beyond the scope of the jurisdiction of the House of Commons, must be considered to be legally sufficient).

Not surprisingly, there are no known cases where a person imprisoned by order of a sitting House of Parliament sought a writ of habeas corpus from a common law court and was discharged by the court.

${ }^{159}$ Habeas corpus proceedings in the High Court of Parliament did not end with the reign of James $I$. Such proceedings continued to occur in the reign of James I's son, Charles I, who reigned from 1625 until 1649, and they also occurred, although with less frequency, during the reign of Charles I's son, Charles II, who reigned from 1660 until 1685. For examples of parliamentary habeas proceedings in the House of Lords during the early part of the reign of Charles I, see In re Richard Tempest (H.L. 1628), in 4 H.L.JouR. 9, 13 (servant of member of House of Lords ordered released from imprisonment violative of parliamentary privilege from arrest); In re John Coore (H.L. 1628), in (1) 3 H.L.Jour. 862, 869, and (2) 11 MHL 213 (same); In re Humphrey Lewes (H.L. 1628), in (1) 3 H.L.JouR. 779, 783, 788, and (2) $11 \mathrm{MHL}$ 212 (same); In re William Brockett (H.L. 1628), in (1) 3 H.L.Jour. 777, 780, and (2) $11 \mathrm{MHL} 212$ (same); In re Jeremy Bygatt (H.L. 1628), in (1) 3 H.L.Jour. 772, 774-75, and (2) $11 \mathrm{MHL} 212$ (same). For habeas proceedings in the House of Commons early in the reign of Charles I, see In re Emanuell Gifford (H.C. 1625), in 1 H.C.Jour. $817,819,820,821$ (member of House of Commons ordered released from imprisonment violative of parliamentary privilege from arrest); In re Sir Thomas Badger's Man (H.C. 1625), in 1 H.C.Jour. 817, 819, 821 (servant of member of House of Commons ordered released from imprisonment violative of parliamentary privilege from arrest). For a habeas corpus proceeding in the House of Lords during the reign of Charles II, see In re John Prosser (H.L. 1669), in 12 H.L.JouR. 258, 260 (servant of peeress ordered released from imprisonment violative of parliamentary privilege from arrest). Future scholarship undoubtedly will explore in detail the various habeas proceedings in the High Court of Parliament in the reigns of Charles I and Charles II.

160 Perhaps the only exception would be those scholarly books and articles which, when focusing on the history of parliamentary privilege, touch upon the 
Scholarly historical writings on the High Court of Parliament as a court of judicature may be grouped into four categories. First, there are the writings on the High Court of Parliament as an omnicompetent court of justice during the Middle Ages. ${ }^{161}$ Second, there is the literature on the House of Lords in its capacity, beginning in the late fourteenth century, as the highest court of appellate jurisdiction of the realm. ${ }^{162}$ Third, there is the literature on the House of Lords as a court of trial jurisdiction in criminal cases where the defendant was a peer entitled, by virtue of privilege of peerage, to be tried in that House rather than a common law court. ${ }^{163}$ Fourth, there is the literature on parliamentary impeachment proceedings, particularly

parliamentary habeas corpus remedy as an incident to their discussion of parliamentary privilege. See, e.g., Erskine May's Treatise on the LaW, Privileges, Proceedings and Usage of Parliament 94-95 (Barnett Cocks ed., 18th ed. 1971); Cart WitTKe, The History of English Parliamentary Privilege 92-94 (1921); G.W. Prothero, The Parliamentary Privilege of Freedom From Arrest, and Sir Thomas Shirley's Case, 1604, 8 Eng. Hist. Rev. 733, 734-37 (1893). See also MaURICE F. Bond, GUIDE to the ReCORdS OF PARLAAMENT 125-26 (1971) (listing, among the records of House of Lords, 900 documents in the Anciliary Privilege Papers, which include writs of habeas corpus of the House of Lords, together with returns to those writs).

161 See, e.g., Charles howard Mcliwain, The High Court of Parliament and Its SuPremacy 109-20 (1910); A.F. Pollard, The Evolution of Parliament 20-43 (2d ed. 1968); J.G. Edwards, "Justice" in Early English Parliaments, 27 BuLl. INSt. Hist. ReSEARCH 35 (1954).

162 See generally 1 WILLIAM HOLDSWORTH, A HISTORY OF ENGLISH LAW 351-77 (7th ed. A.L. Goodhart \& H.G. Hanbury eds., 1956) (surveying history of judicial power of House of Lords and examining the appellate authority of that House to review judgments of both common law courts and Court of Chancery; that the House of Lords alone could correct judgments of Court of King's Bench was generally recognized a century before 1485). In 2009, the appellate jurisdiction of the House of Lords was transferred to the newly created Supreme Court of the United Kingdom. The House of Lords, therefore, is no longer England's highest appellate court.

${ }^{163}$ Privilege of peerage was the right of a peer of England to be tried for treason or felony (but not misdemeanor) in the House of Lords itself rather than in any other court. See generally 1 WILLIAM HOLDSWORTH, A HISTORY OF ENGLISH LAW 385-90 (7th ed. A.L. Goodhart \& H.G. Hanbury eds., 1956) (examining history and development of privilege of peerage); Colin Rhys Lovell, The Trial of Peers in Great Britain, 55 AM. HIST. Rev. 69 (1949) (stating that under privilege of peerage, House of Lords had sole original jurisdiction over peers and peeresses charged with treason or felony).

Privilege of peerage was abolished in 1948. Criminal Justice Act, 1948, 11 \& 12 Geo. 6, c. 58, §30 (Eng.). 
those in the fourteenth ${ }^{164}$ and seventeenth ${ }^{165}$ centuries. This Article creates-and at the same time contributes to-a necessary fifth category of scholarship on the High Court of Parliament: writings on the High Habeas Court of Parliament.

Parliamentary habeas corpus proceedings in the reign of James I constitute an important part of English legal history that no longer can be ignored. These proceedings not only broaden our understanding of Parliament, but also add a fresh chapter to arguably the greatest of all legal stories - "The Story of the Habeas Corpus."166

${ }^{164}$ See, e.g., Margaret Aston, The Impeachment of Bishop Despenser, 38 BULL. INST. HIST. ResearCH 127 (1965); J.G. Bellamy, Appeal and Impeachment in the Good Parliament, 39 BULL. INST. HIST. RESEARCH 35 (1966); Gabrielle Lambrick, The Impeachment of the Abbot of Abingdon in 1368, 82 ENG. Hist. Rev. 250 (1967); N.B. Lewis, Article VII of the Impeachment of Michael de la Pole in 1386, 42 ENG. HIST. REV. 402 (1927); J.J.N. Palmer, The Impeachment of Michael de la Pole, 42 BULL. INST. HIST. RESEARCH 96 (1969); T.F.T. Plucknett, Impeachment and Attainder, 3 TrANSACTIONS ROYAL HIST. SOC'Y 5th 145 (1953); T.F.T. Plucknett, The Impeachments of 1376, 1 TranSACTIONS ROYAL HIST. SOC'Y 5th 160 (1951); T.F.T. Plucknett, The Origin of Impeachment, 24 Transactions Royal Hist. SOC'Y 4th 47 (1942).

${ }^{165}$ See, e.g., Colin G.C. Tite, Impeachment and Parllamentary Judicature in Early Stuart England (1974); Allen Horstman, A New Curia Regis: The Judicature of the House of Lords in the 1620s, 25 Hist. J. 411 (1982); Damien X. Powell, Why Was Sir Francis Bacon Impeached? The Common Lawyers and the Chancery Revisited: 1621, 81 HIstoRY 511 (1996); Clayton Roberts, The Impeachment of the Earl of Clarendon, 13 CAMBRIDGE HIST. J. 1 (1957); Clayton Roberts, The Law of Impeachment in Stuart England: A Reply to Raoul Berger, 84 YALE L.J. 1419 (1975); Harry F. Snapp, The Impeachment of Roger Maynwaring, 30 HUNTINGTON LIBR. Q. 217 (1967); W.R. Stacey, Impeachment, Attainder, and the "Revival" of Parliamentary Judicature under the Early Stuarts, 11 PARLIAMENTARY HISTORY 40 (1992).

${ }^{166}$ See Edward Jenks, The Story of the Habeas Corpus, 18 Law Q. Rev. 64 (1902). 


\section{APPENDIX 1}

A List and Summary of the Habeas Corpus Proceedings in the High Court of Parliament, 1603-1625 167

Part A

Habeas Corpus Proceedings in the House of Lords, 1603-1625

1. In re Thomas Rush (H.L. 1604), in 2 H.L.JouR. 270, 271, 274, 275 (Mar. 31, Apr. 2, 5, 11, 1604). Servant of lord temporal. Unclear whether relief granted.

2. In re William Allome (H.L. 1604), in 2 H.L.Jour. 285, 286, 29091 (Apr. 26, May 1, 1604). Claimed to be servant of lord temporal. Relief denied. Allome was not "a menial or ordinary Servant" and hence "was not ... . a Person privilegeable from this Arrest".

3. In re John Piggott (H.L. 1604), in 2 H.L.Jour. 296 (May 10, 1604). Servant of lord temporal. Unclear whether relief granted.

4. In re Robert Quinell (H.L. 1604), in 2 H.L.JouR. 299-300 (May $15,1604)$. Servant of lord spiritual. Unclear whether relief granted.

5. In re Nicholas Reading (H.L. 1604), in 2 H.L.JouR. 308, 312-13, 317, 318 (May 28, June 4, 9, 11, 1604). Royal servant. Relief granted.

6. In re Marmaduke Redmaine (H.L. 1604), in 2 H.L.Jour. 315, $316-17,327,337,341$ (June 7, 9, 23, July 2, 5, 1604). Servant of lord temporal. Relief granted.

7. In re Thomas Musgrove (H.L. 1607), in 2 H.L.Jour. 497, 498 (Mar. 30, 31, 1607). Servant of lord temporal. Relief granted.

8. In re Nathaniell Butler (H.L. 1607), in 2 H.L.Jour. 509, 510 (May $16,18,1607)$. Servant of lord temporal. Relief granted.

9. In re John Foster (H.L. 1607), in 2 H.L.JouR. 511, 512, 514-15 (May 20, 27, 28, 1607). Servant of lord temporal. Relief granted.

${ }^{167}$ In all the cases in Parts A and B, habeas relief was sought or granted solely on grounds involving the parliamentary privilege of freedom from arrest. All but three of the cases involved imprisonment pursuant to civil arrest process. 
10. In re John Danson (H.L. 1607), in 2 H.L.Jour. 513-14, 515 (May $28,30,1607)$. Claimed to be servant of lord temporal. Relief denied. Danson was not "ordinary and menial Servant" and "did carry himself therein fraudulently".

11. In re William Heylocke (H.L. 1610), in 2 H.L.Jour. 588 (May 5, 1610). Servant of lord temporal. Unclear whether relief granted.

12. In re William Lodar (H.L. 1610), in (1) 2 H.L.JouR. 597-98, 599 (May 23, 24, 1610), and (2) HMC 4th 119 (May 23, 1610). Servant of lord temporal. Relief granted.

13. In re Roger Bradshaw (H.L. 1614), in 2 H.L.JouR. 691, 692, 695 (Apr. 11, 14, 19, 1614). Servant of lord temporal. Unclear whether relief granted.

14. In re George Belgrave (H.L. 1614), in 2 H.L.JouR. 694, 695, 695-96, 697-98 (Apr. 16, 18, 19, May 3, 1614). Servant of lord temporal. Relief granted.

15. In re Sir David Wood (H.L. 1614), in 2 H.L.JouR. 710, 712 (May $30,31,1614)$. Servant of lord temporal. Relief granted.

16. In re Richard Taylor (H.L. 1614), in 2 H.L.Jour. 712 (May 31, 1614). Servant of lord temporal. Relief granted.

17. In re John Robinson (H.L. 1620/1), in (1) 3 H.L.Jour. 25, 30, 31 (Feb. 21, 26, 27, 1620/1), and (2) 11 MHL 135 (Feb. 26, $1620 / 1)$. Servant of lord temporal. Relief granted.

18. In re Solomon Browne (H.L. 1620/1), in (1) 3 H.L.JouR. 27-28, 28-29, 30 (Feb. 23, 24, 26, 1620/1), (2) HMC 3d 18 (Feb. 23, 1620/1), and (3) $11 \mathrm{MHL} 134$ (Feb. 23, 1620/1). Servant of lord spiritual. Relief granted.

19. In re William Jewell (H.L. 1620/1), in 3 H.L.JouR. 45 (Mar. 15, $1620 / 1)$. Servant of lord temporal. Relief granted.

20. In re Sir Henry Fynes (H.L. 1621), in (1) 3 H.L.JouR. 88-89, 96 (Apr. 26, 28, 1621), (2) HMC 3d 22 (Apr. 26, 1621), and (3) 11 MHL 146 (Apr. 26, 1621). Royal servant. Relief granted.

21. In re Francis Broade (H.L. 1621), in (1) 3 H.L.JouR. 94, 96 (Apr. 27, 28, 1621), (2) HMC 3d 22 (Apr. 27, 1621), and (3) $11 \mathrm{MHL}$ 146 (Apr. 27, 1621). Nonservant. Relief granted. 
22. In re John Nanton (H.L. 1621), in (1) 3 H.L.Jour. 97, 119-20, 133 (Apr. 28, May 12, 26, 1621), (2) HMC 3d 22 (Apr. 28, 1621), and (3) 11 MHL 147 (May 16, 1621). Servant of lord temporal. Relief granted.

23. In re John Nonne (H.L. 1621), in (1) 3 H.L.Jour. 119, 119-20, 122 (May 12, 14, 1621), and (2) 11 MHL 147 (May 12, 1621). Servant of lord temporal. Relief granted.

24. In re Originall Bellamye (H.L. 1621), in (1) 3 H.L.Jour. 136, 156 (May 28, June 4, 1621), and (2) 11 MHL 152 (May 29, 1621). Royal servant. Relief granted.

25. In re Richard Dyke (H.L. 1621), in (1) 3 H.L.Jour. 165, 170 (Nov. 22, 26, 1621), and (2) 11 MHL 153 (Nov. 22, 1621). Nonservant. Relief granted.

26. In re William Cowse (H.L. 1621), in (1) 3 H.L.Jour. 169, 170 (Nov. 24, 26, 1621), and (2) $11 \mathrm{MHL}$ 153-56 (Nov. 24, 1621). Servant of lord temporal. Unclear whether relief granted.

27. In re Benjamin Crokey (H.L. 1621), in (1) 3 H.L.Jour. 170-71, 173-74 (Nov. 26, 28, 1621), and (2) 11 MHL 156 (Nov. 26, 1621). Nonservant. Relief granted.

28. In re William Whorewood (H.L. 1621), in (1) 3 H.L.Jour. 176, 179 (Nov. 30, Dec. 3, 1621), and (2) 11 MHL 157 (Dec. 1, 1626). Servant of lord temporal. Relief granted.

29. In re Henry Lucye (H.L. 1621), in (1) 3 H.L.JouR. 182, 187 (Dec. 5, 8, 1621), and (2) $11 \mathrm{MHL} 157$ (Dec. 6, 1621). Servant of lord temporal. Relief granted.

30. In re Abraham Watts (H.L. 1621), in (1) 3 H.L.JouR. 192, 193, 196 (Dec. 12, 13, 15, 1621), and (2) 11 MHL 157 (Dec. 14, 1621). Servant of lord temporal. Relief granted.

31. In re George Hume (H.L. 1621), in (1) 3 H.L.Jour. 198, 199 (Dec. 17, 18, 1621), and (2) 11 MHL 157 (Dec. 17, 1621). Servant of lord temporal. Relief granted.

32. In re John Phillipps (H.L. 1623/4), in (1) 3 H.L.Jour. 247, 256 (Mar. 5, 11, 1623/4), and (2) 11 MHL 159 (Mar. 9, 1623/4). Royal servant. Relief granted. 
33. In re Sir Edward Osbaldeston (H.L. 1623/4), in (1) 3 H.L.Jour. 161, 262, 264 (Mar. 13, 15, 16, 1623/4), (2) HMC 3d 29 (Mar. 13, 1623/4), and (3) 11 MHL 159 (Mar. 15, 1623/4). Servant of lord temporal. Relief granted.

34. In re Welsbourne Sill (H.L. 1624), in (1) 3 H.L.Jour. 385, 386 (May 14, 15, 1624), and (2) 11 MHL 160 (May 14, 1624). Servant of lord temporal. Relief granted.

35. In re Richard Culpeper (H.L. 1624), in (1) 3 H.L.JouR. 415, 421 (May 28, 29, 1624), and (2) 11 MHL 163 (May 28, 29, 1624). Servant of lord temporal. Relief granted.

\section{Part B}

Habeas Corpus Proceedings in the House of Commons, 1603-1625

1. In re Sir Thomas Shirley (H.C. 1603/4, 1604), in (1) 1 H.C.Jour. $149,155,167-68,171,200,202-03,204-05,205-06,206-07$, 208, 209-10, 210-11, 211, 213, 215 (Mar. 22, 1603/4; Mar. 27, Apr. 11, May 7, May 8, 9, 10, 11, 12, 14, 15, 16, 17, 19, 1604), and (2) 1 HATSELL 157-60. Member of Parliament. Relief granted.

2. In re Roger Brereton (H.C. 1605/6), in (1) 1 H.C.JouR. 262-63, 267, 269 (Feb. 3, 13, 15, 1604/5), and (2) 1 HATSELL 132. Member of Parliament. Relief granted.

3. In re Sir Edwyn Sandy's Servants (H.C. 1605/6), in (1) 1 H.C.Jour. 270, 272, 272-73 (Feb. 18, 19, 21, 22, 1605/6), and (2) 1 HATSELL 132-33. Servant. Unclear whether relief granted.

4. In re Thomas Finch (H.C. 1606/7), in (1) 1 H.C.Jour. 332, 334 (Feb. 10, 13, 1606/7), and (2) 1 HatSELL 161. Servant. Relief granted.

5. In re Nicholas Hawkins (H.C. 1606/7), in (1) 1 H.C.Jour. 338, 339 (Feb. 20,1606/7), and (2) 1 HATSELL 162. Servant. Mediated.

6. In re Sir Vincent Skinner (H.C. 1610), in 2 FOSTER 306-08 (Oct. 30, 1610). Member of Parliament. Relief granted.

7. In re Sir William Bamfeild (H.C. 1614), in (1) 1 H.C.Jour. 458, 464, 466 (Apr. 9, 14, 16, 1614), and (2) 1 HatSELL 133. Member of Parliament. Unclear whether relief granted. 


\section{APPENDIX 2}

Writs of Habeas Corpus Issued by Order of the House of Lords During the Reign of James I, and Returns Thereto, Preserved in the Parliamentary Archives

1. In re John Robinson (1620/1)

Writ: $2 \frac{1}{2}$ inches high by 12 inches wide

Return: 11 inches high by $11 \frac{1}{2}$ inches wide

Referenced in Parliamentary Archives:

$\mathrm{HL} / \mathrm{PO} / \mathrm{JO} / 10 / 14 / 2 / 3339$

2. In re Solomon Browne (1620/1)

Writ: $2 \frac{1}{2}$ inches high by 11 inches wide

Return: $93 / 4$ inches high by $11 \frac{1}{2}$ inches wide

Referenced in Parliamentary Archives:

$\mathrm{HL} / \mathrm{PO} / \mathrm{JO} / 10 / 14 / 2 / 3338$

[N.B. - These are the first of the two writs and two returns in this case.]

3. In re Solomon Browne (1620/1)

Writ: $2 \frac{1}{2}$ inches high by 11 inches wide

Return: $93 / 4$ inches high by $12 \frac{1}{2}$ inches wide

Referenced in Parliamentary Archives:

$\mathrm{HL} / \mathrm{PO} / \mathrm{JO} / 10 / 14 / 2 / 3338$

[N.B.-These are the second of the two writs and two returns in this case.]

4. In re Sir Henry Fynes (1621)

Writ: $2 \frac{1}{2}$ inches high by $111 \frac{1}{2}$ inches wide

Return: 7 inches high by 11 inches wide

Referenced in Parliamentary Archives:

$\mathrm{HL} / \mathrm{PO} / \mathrm{JO} / 10 / 14 / 2 / 3348$

5. In re Francis Broade (1621)

Writ: $2 \frac{1}{2}$ inches high by 12 inches wide

Return: 11 inches high by 11 inches wide

Referenced in Parliamentary Archives:

$\mathrm{HL} / \mathrm{PO} / \mathrm{JO} / 10 / 14 / 2 / 3349$

6. In re John Nonne (1621)

Writ: 2 inches high by $12 \frac{1}{2}$ inches wide

Return: 6 inches high by $11 \frac{1}{2}$ inches wide

Referenced in Parliamentary Archives:

$\mathrm{HL} / \mathrm{PO} / \mathrm{JO} / 10 / 14 / 2 / 3352$ 
7. In re John Nanton (1621)

Writ: $2 \frac{1}{2}$ inches high by 11 inches wide

Return: $3 \frac{3}{4}$ inches high by $101 / 2$ inches wide

Referenced in Parliamentary Archives:

$\mathrm{HL} / \mathrm{PO} / \mathrm{JO} / 10 / 14 / 2 / 3353$

8. In re Originall Bellamye (1621)

Writ: 2 inches high by 9 inches wide

Return: 8 inches high by 9 inches wide

Referenced in Parliamentary Archives:

$\mathrm{HL} / \mathrm{PO} / \mathrm{JO} / 10 / 14 / 2 / 3356$

9. In re Richard Dyke (1621)

Writ: 2 inches high by $13 \frac{1}{2}$ inches wide

Return: 6 inches high by 11 inches wide

Referenced in Parliamentary Archives:

$\mathrm{HL} / \mathrm{PO} / \mathrm{JO} / 10 / 14 / 2 / 3361$

10. In re Benjamin Crokey (1621)

Writ: $2 \frac{1}{2}$ inches high by $12 \frac{1}{2}$ inches wide

Return: $4 \frac{1}{2}$ inches high by 14 inches wide

Referenced in Parliamentary Archives:

$\mathrm{HL} / \mathrm{PO} / \mathrm{JO} / 10 / 14 / 4 / 3363$

11. In re William Whorewood (1621)

Writ: $2 \frac{1}{2}$ inches high by $12 \frac{1}{2}$ inches wide

Return: $8 \frac{1}{2}$ inches high by $11 \frac{1}{2}$ inches wide

Referenced in Parliamentary Archives:

$\mathrm{HL} / \mathrm{PO} / \mathrm{JO} / 10 / 14 / 4 / 3364$

12. In re Henry Lucye (1621)

Writ: 2 inches high by $13 \frac{1}{2}$ inches wide

Return: 12 inches high by $12 \frac{1}{2}$ inches wide

Referenced in Parliamentary Archives:

$\mathrm{HL} / \mathrm{PO} / \mathrm{JO} / 10 / 14 / 4 / 3365$

13. In re Abraham Watts (1621)

Writ: $2 \frac{1}{2}$ inches high by $12 \frac{1}{2}$ inches wide Return: $4 \frac{1}{2}$ inches wide by 11 inches wide Referenced in Parliamentary Archives:

$\mathrm{HL} / \mathrm{PO} / \mathrm{JO} / 10 / 14 / 4 / 3366$ 
14. In re George Hume (1621)

Writ: $2 \frac{1}{2}$ inches high by $12 \frac{1}{2}$ inches wide

Return: $12 \frac{1}{2}$ inches high by $10 \frac{1}{2}$ inches wide

Referenced in Parliamentary Archives:

$\mathrm{HL} / \mathrm{PO} / \mathrm{JO} / 10 / 14 / 4 / 3367$

15. In re John Phillipps (1623/4)

Writ: $2 \frac{1}{2}$ inches high by $131 / 2$ inches wide

Return: $12 \frac{1}{2}$ inches high by 13 inches wide

Referenced in Parliamentary Archives:

$\mathrm{HL} / \mathrm{PO} / \mathrm{JO} / 10 / 14 / 4 / 3377$

16. In re Sir Edward Osbaldeston (1623/4)

Writ: $23 / 4$ inches high by 14 inches wide Return: $6 \frac{1}{2}$ inches high by 14 inches wide Referenced in Parliamentary Archives: $\mathrm{HL} / \mathrm{PO} / \mathrm{JO} / 10 / 14 / 4 / 3378$

17. In re Wellsbourne Sill (1624)

Writ: $1 \frac{1}{2}$ inches high by 13 inches wide Return: $7 \frac{1}{4}$ inches high by $121 \frac{1}{2}$ inches wide Referenced in Parliamentary Archives: $\mathrm{HL} / \mathrm{PO} / \mathrm{JO} / 10 / 14 / 4 / 3380$

18. In re Richard Culpeper (1624)

Writ: $2 \frac{1}{2}$ inches high by 12 inches wide Return: $3 \frac{1}{2}$ inches high by $11 \frac{112}{2}$ inches wide Referenced in Parliamentary Archives: $\mathrm{HL} / \mathrm{PO} / \mathrm{JO} / 10 / 14 / 4 / 3385$ 


\section{APPENDIX 3}

Reduced Facsimile Photograph of House of Lords Writ of Habeas Corpus to Produce Richard Culpeper, Issued on May 28, $1624^{168}$

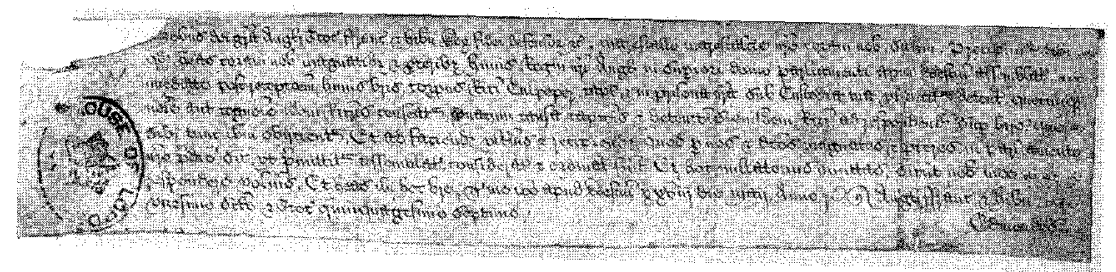
168 The original parchment document is $2 \frac{1}{2}$ inches high by 12 inches wide. See
supra, Appendix 2 . 
